\title{
Image and Incarnation
}

The Early Modern Doctrine of the Pictorial Image

\author{
Edited by
}

Walter S. Melion and Lee Palmer Wandel

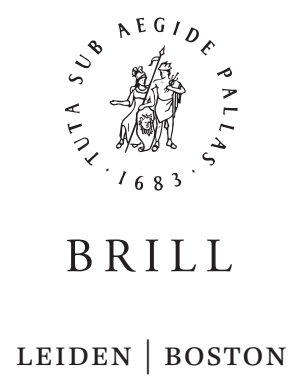

For use by the Author only | (C) 2015 Koninklijke Brill NV 


\section{Contents}

Acknowledgments IX

Notes on the Editors $\mathrm{X}$

Notes on the Contributors XI

List of Illustrations XVII

Introduction 1

Walter S. Melion and Lee Palmer Wandel

PART 1

Representing the Mystery of the Incarnation

1 Medietas / Mediator and the Geometry of Incarnation 17 Herbert L. Kessler

2 Mute Mysteries of the Divine Logos: On the Pictorial Poetics of Incarnation 76

Klaus Krüger

3 A Meaty Incarnation: Making Sense of Divine Flesh for Aztec

Christians 109

Jaime Lara

4 The Ineffability of Incarnation in Le Brun's Silence or Sleep of the Child 137

Matthieu Somon

PART 2

Imago Dei and the Incarnate Word

5 Thomas Aquinas, Sacramental Scenes, and the 'Aesthetics' of Incarnation 161

Mark D. Jordan

6 The Poetics of the Image in Late Medieval Mysticism 173

Niklaus Largier

For use by the Author only | (C) 2015 Koninklijke Brill NV 
7 Incarnation, Image, and Sign: John Calvin's Institutes of the Christian Religion \& Late Medieval Visual Culture $\quad 187$

Lee Palmer Wandel

8 Eye to Eye, Text to Image? Jan Provoost's Sacred Allegory, Jan van Ruusbroec's Spieghel der eeuwigher salicheit, and Mystical Contemplation in the Late Medieval Low Countries 203 Geert Warnar

9 'A Just Proportion of Body and Soul': Emblems and Incarnational Grafting 231

Christopher Wild

\section{PART 3}

Literary Figurations of the Incarnation

10 From Negative Painting to Loving Imprint in Pierre De Bérulle's Discours (1623) 253

Agnès Guiderdoni

11 Discerning Vision: Cognitive Strategies in Cornelis Everaert's Mary Compared to the Light (ca. 1511) 264

Bart Ramakers

12 The Fountain of Life in Molinet's Roman de la rose moralisé (1500) 313

Michael Randall

PART 4

Transformative Analogies of Matter and Spirit

13 Figuring the Threshold of Incarnation: Caravaggio's Incarnate Image of the Madonna of Loreto 341

Ralph Dekoninck

14 Super-Entanglement: Unfolding Evidence in Hieronymus Bosch's Mass of St. Gregory 371

Reindert Falkenburg 
15 The Mystery of the Incarnation and the Art of Painting 397 Dalia Judovitz

16 Convent and Cubiculum Cordis: The Incarnational Thematic of Materiality in the Cistercian Prayerbook of Martin Boschman (1610) 413

Walter S. Melion

\section{PART 5}

Visualizing the Flesh of Christ

17 Dieu le Père en Vierge Marie. La Trinité - Pietà de Rubens 461 Colette Nativel

18 Images of the Incarnation in the Jesuit Japan Mission's Kirishitanban Story of Virgin Martyr St. Catherine of Alexandria 489 Haruko Nawata Ward

Index Nominum 511 


\title{
Discerning Vision: Cognitive Strategies in Cornelis Everaert's Mary Compared to the Light (ca. 1511)
}

\author{
Bart Ramakers
}

\section{Play and Characters}

Among the extensive dramatic oeuvre of the Flemish playwright Cornelis Everaert - principal poet of the chamber of rhetoric called The Holy Ghost of Bruges, fuller and dyer, clerk of the local drapers' guild - are four so-called 'comparations' ('comparaties'). ${ }^{1}$ These are dramatized comparisons between on the one hand an object of devotion, and on the other a Biblical object or city, an object from daily life, a natural phenomenon, or living creature. ${ }^{2}$ Thus, Everaert compares the apostle Peter to a dove and Mary to the throne of Solomon, the city of Jerusalem, a merchant ship, and light, respectively. Comparations basically follow the structure of the spel van zinne, the Dutch equivalent of the morality play, ${ }^{3}$ in the sense that a character who represents mankind goes in search of the answer to a particular question, in casu how Mary (or Peter) can

1 For editions of and introductions to these plays, see Hüsken W.N.M. (ed.), De Spelen van Cornelis Everaert, 2 vols. (Hilversum: 2005). The form and content of the comparations have been the subject of studies by Ramakers B., Spelen en figuren. Toneelkunst en processiecultuur in Oudenaarde tussen middeleeuwen en moderne tijd (Amsterdam: 1996) 387-389, and Moser N., "Maria verklaard. Everaert als exegeet in Maria ghecompareirt byde claerheyt (1511)", in Dijk H. van - Ramakers R. et al., Spel en spektakel. Middeleeuws toneel in de Lage Landen, Nederlandse literatuur en cultuur in de middeleeuwen 23 (Amsterdam: 2001) 246-262, 369377; and Moser N., De strijd voor rhetorica. Poëtica en positie van rederijkers in Vlaanderen, Brabant, Zeeland en Holland tussen ca. 145 o en ca. 1620 (Amsterdam: 2001) 135, 141-146, 155-157.

2 In another genre practiced by Everaert, the so-called table play, objects are allegorized and subsequently presented to the person in whose honor the play is being performed. See: Ramakers B., "Book, Beads and Bitterness: Making Sense of Gifts in Two Table Plays by Cornelis Everaert”, in Corbellini S. - Hoogvliet M. - Ramakers B. (eds.), Discovering the Riches of the Word: Religious Reading in Medieval and Early Modern Times, Intersections: Studies in Early Modern Culture 38 (Leiden - Boston: 2015), 141-170.

3 On this genre, see Ramakers B., "Dutch Allegorical Drama: Tradition and Conceptual Approach", in Strietman E. - Happé P. (eds.), Urban Theatre in the Low Countries, 1400-1625, Medieval Texts and Cultures of Northern Europe 12 (Turnhout: 2006) 127-147. 
be compared in all their spiritual properties to the aforementioned objects in all their material characteristics. The plays were performed in the early decades of the sixteenth century during theatrical competitions linked to a series of processions - mainly in honor of the Blessed Virgin — held in the Flemish coastal towns of Nieuwpoort and Veurne.

As theatre, these plays combine word and image. The latter not only manifests itself in personifications, particularly in their costumes and attributes, in their mimicry and gestures, as well as in their overall action on stage, but also in the use of living images or tableaux vivants, which served argumentative, devotional and mnemonic purposes. In four of the five specimens the interplay of word and image amounts mainly to catechetical instruction: the characteristics and qualities of the comparandum are explained and illustrated through comparison. The sensory perception of the plays' action, its external aspect, primarily leads to rational insight, as shown from the reactions of the human characters in them. However, in one of them, Mary Compared to the Light (Maria Ghecompareirt by de Claerheyt), the mankind character does not perceive the comparison outwardly, at least as far as the visual action is concerned, but inwardly, as the mankind character in this play is blind. His name is Imaginative Mind (Ymagineirlic Gheest). He enters the stage from the audience, desiring to experience how Mary can be compared to light. He is the exemplary spectator, representing all those watching and listening to the play. It was written for a dramatic contest held in 1511 or 1512 in Nieuwpoort, probably on occasion of the town's annual Corpus Christi procession. ${ }^{4}$

Although for reasons of simplicity I use the word 'light', the Middle Dutch term used by Everaert (almost) throughout his play is 'claerheyt' ('clarity'). In all likelihood the organizers consciously used the word 'claerheyt' in their invitation to the contest, in order to refer to what light achieves in its modern-day meaning of a beam of electromagnetic radiation, namely clearness, brightness, splendor, or indeed, clarity, but also effects such as color, reflection, heat and warmth. ${ }^{5}$ In fact, medieval light terminology was highly differentiated. ${ }^{6}$

4 Hüsken, De Spelen II 751; and Van Bruaene A.-L., Om beters wille. Rederijkerskamers en de stedelijke cultuur in de Zuidelijke Nederlanden 1400-1650 (Amsterdam: 2008) 209, esp. n. 85.

5 In those passages where the Latin Vulgate and vernacular Dutch Bible translations use the word 'claritas' and 'clearheyt' respectively, it always refers to the radiant effect of light or to radiance in a spiritual sense (Wisdom 7:25; Luke 2:9; 1 Corinthians 15:41; 2 Corinthians 4:6; Acts 22:11).

6 Hedwig K., Sphaera Lucis. Studien Zur Intelligibilität des Seienden im Kontext der mittelalterlichen Lichtspekulation, Beiträge zur Geschichte der Philosophie und Theologie des Mittelalters, Neue Folge 18 (Münster: 1980) 13 . 
Imaginative Mind is advised by three characters, personifications like him, who each fulfil a clearly demarcated role in accordance with the kind of argument or reasoning they represent. The first is called Experiential Proof (Experientich Bethooch), who, according to a stage direction, is 'dressed like an honourable man.7 That Everaert—and the organizers of the Nieuwpoort contest - aimed for a truly scientific analogy, is made clear by Experiential Proof not only through his name, but also through his sustained analysis of light on the basis of scientific observation, that is, on the basis of knowledge received through the senses. Although he occasionally appeals to auctoritates, ${ }^{8}$ he persistently describes the effects of light in empirical terms, even explicitly, by introducing them with expressions such as 'as we may see [learn] through experience. ${ }^{9}$ We should keep in mind that the kind of empiricism practiced in the Middle Ages was not exclusively based on personal experimental observation, but could include empirical data from the past, either collected by the author himself or by others, passed down through manuscript and print, and thought experiments. ${ }^{10}$ In fact, education in natural philosophy was dominated by reading and textual commentary. ${ }^{11}$ The period nevertheless witnessed an increasing engagement with the sensory details of natural phenomena. ${ }^{12}$

Opposite Experiential Proof's physical analysis of the comparans light, the second advisor, Sweet Eloquence (Soetzinneghe Eloquencie), supplies the theological analysis of the comparandum Mary. As the personification of the art of rhetoric or poetry, she — this character is called a 'woman' ('vrau') ${ }^{13}$ —is able not only to fathom the analogy between Mary and light, but also to phrase this analogy in a rhetorically convincing way, whereby the persuasiveness depends not only on the origin and quality of the arguments as such-most are taken from Scripture and authorities — but also on the quality of their poetic

$7 \quad$ Above vs. 1: 'gheabytuweirt als een man edelic'. Citations from the play are taken from the edition by Hüsken (Hüsken, De Spelen II, 747-784). In some instances my punctuation and interpretation differs from that of the editor.

8 Vss. $482,486,641$.

9 Vs. 665: 'zo men zien mach by exsperiencie'. Also see this characters's use of exsperient (vs. 301), exsperiencie ( $n$ ) (vss. 450, 534), exsperientelic (vss. 384, 574) and exsperientich (641).

10 Grant E., Planets, Stars, and Orbs: The Medieval Cosmos, 1200-1687 (Cambridge: 1994) 221224. On experientia, see Grant, Planets, Stars, and Orbs 201.

11 Park K., "Observation in the Margins, 500-1500", in Daston L. - Lunbeck E. (eds.), Histories of Scientific Observation (Chicago - London: 2011) 15-44, esp. 15-17; and Pomata G., "Observation Rising: Birth of an Epistemic Genre, 1500-1650", in ibid., 45-80, esp. 45-46. Biernoff S., Sight and Embodiment in the Middle Ages (New York: 2002) 64-65; and Park, "Observation in the Margins" 35 .

13 Vs. 2. 
expression. Sweet Eloquence's name hints at this direction. Her verbal presence goes further than just providing a doctrinal interpretation of the Virgin per se. She also aims to venerate her. Sweet Eloquence covers her arguments in laudatory expressions that contribute to an atmosphere of worship and devotion. Indeed, from a certain point onwards she no longer speaks about Mary in the third person, but addresses her in the second person, directly, perhaps even literally, in the sense that she turns towards a visual representation of the Blessed Virgin. A painting or statue situated on or near the stage is one possibility. Almost without exception she starts her clauses with two-line apostrophes consisting of the name 'Mary' and the word 'clarity', such as 'Oh Mary, clarity, steeped in virtue, / in pure hearts you abundantly shine.'14

It is not Sweet Eloquence, however, who starts addressing Mary directly. It is the third participant in the comparation, called Grounded Scripture (Ghefondeirde Scriftuere), who does so. She - this is again a female character, 'spiritually dressed' ('gheestelicken ghecleet'), with a burning candle in her hand ${ }^{15}$ - is not on stage from the beginning, but appears halfway through the prologue, shortly after Experiential Proof and Sweet Eloquence have lifted Imaginative Mind onto the stage from among the audience. The three of them start looking for her, since her presence is indispensable to explaining the previously mentioned analogy. She has to provide the written basis-quotes of the prophets, doctors of the Church and liturgical prayers-for the comparison between Mary and light. She addresses Mary by paraphrasing Canticles 4:7: "You are indeed the light, according to the word / of the Canticle "fair and flawless" ${ }^{16}$ In fact, Grounded Scripture starts most of her clauses by quoting or paraphrasing a Bible book or an authority, often referring to that book's title or that authority's name, such as 'Saint Bernard, / filled with contemplation, / says. ${ }^{\prime 17}$

The action in this comparation is predominantly verbal and static, consisting of a series of discursive exchanges devoted to the various aspects of the comparison, in which the characters take turns according to a regular pattern that will be described in more detail below. The act of comparing is referred to

\footnotetext{
14 Vss. 541-542: 'O Maria, claerheyt, der duechden bewynsels, / in reyne herten ghy overvloedich rayt'.

15 Vs. 104.

16 Vss. 230-240: 'Ghy zyt wel de claerheyt, naer de verhalichede / van der Cantycke "zuver ende net gheheel"'.

17 Vss. 495-496: 'Den heleghen Bernaerdus, / vul contemplacien, / seght'.
} 
by the verb 'compareren' or 'ghelycken' ('to compare') and countless instances of the adverb 'gelijk' ('like' or 'just as'). ${ }^{18}$

Besides the characters' appearance and apparel, the visual in this play is represented by two living images or tableaux vivants. One of them, situated at the end of the prologue, provides the spectators with an analogue for Mary in the well-established tradition of typology, that of Queen Esther kneeling before Ahasuerus (Esther 8:3), which appears in both the Biblia Pauperum and the Speculum Humanae Salvationis - the main medieval typological treatises-where it functions as a prefiguration of the death of the Virgin and her coronation in heaven respectively. The redemptive significance of this event-Mary interceding for mankind because of her closeness to the Trinityis also expressed by the second tableau vivant, which is revealed at the end of the comparation: Mary standing between heaven and earth, as Mediatrix between the Trinity, which is enthroned above, and mankind situated below. This tableau was inspired by the woman from the Book of Revelation (12:1-6).

\section{Approach and Plan}

The condition that makes it impossible for Imaginative Mind to see either comparans or comparandum but allows him to imagine their characteristics and qualities, illustrates that seeing and understanding in this play are not so much a matter of corporeal sight, but also — or even primarily — a matter of spiritual sight, a function of the internal senses, among which imagination took pride of place. ${ }^{19}$ As we shall see, this kind of seeing was supposed to lead man from earthly wisdom, or scientia, to divine wisdom, or sapientia. Being blind, Imaginative Mind is simply forced to employ the kind of vision the rest of the audience can use voluntarily.

I am not primarily concerned here with imagination in its present-day meaning of the power of literary, figurative or mimetic invention, but rather, with the creative or artistic aspect of image-making that in medieval times was closely related to the cognitive one. ${ }^{20}$ Poets as well as painters created verbal

18 Vss. 2, 10, 42, 55a ('compareren'); vss. 70, 124, 446, 689 'ghelycken'). Also see the nouns 'comparacie' (vs. 207) and 'ghelyckenesse' (vs. 646).

19 Biernoff, Sight and Embodiment 81-144; Woolgar C.M., The Senses in Late Medieval England (New Haven - London: 2006) 20-21; Rothstein B.T., Sight and Spirituality in Early Netherlandish Painting (Cambridge: 2006) 36-37; Schumacher L., Divine Illumination: The History and Future of Augustine's Theory of Knowledge (Chichester: 2011) 91; and Williamson B., "Sensory Experience in Medieval Devotion", Speculum 88 (2013) 1-43, esp. 3-4. 
and visual images that were thought to be the outcome of the applicationconsciously or unconsciously-of imagination in its meaning of the internal sense or faculty of knowing. In the creative process, mental images thus led to artistic images through reproductive imagination. ${ }^{21}$ In fact, aesthetic theorists generally point out that art-or the beauty of art for that matter-depends on drawing analogies. ${ }^{22}$ After all, we can only apprehend an object through metaphor. Describing it in terms of all its properties would be an endless task. ${ }^{23}$ The creation of literature or art can be defined as 'a kind of comparative brooding over mental images'.24 Imagination, together with contemplation and meditation, played a significant role in medieval aesthetics. ${ }^{25}$

As I hope to make clear, Mary Compared to the Light exemplifies the working of imagination, not only by featuring a personification of it, but also by showing how this faculty was used to produce, analyze and understand light as a natural analogy of - or metaphor for-Mary and her supernatural significance. At the end it even confronts the audience with a living image or tableau vivant that can be seen as a creative, artistic product of imagination, elevating Imaginative Mind's understanding of Mary to the level of spiritual vision, and thus completing the aforementioned trajectory from scientia to sapientia. Everaert's play, then, is epistemological, demonstrating to its audience how thinking evolves, and how knowledge about the spiritual realm can be extracted from the material world. The use of imagination went even further than establishing parallels or connections between the visible and the invisible. It also was an instrument with which to explore and understandor, better, experience - the object of veneration, Mary, in a spiritual, meditative manner. It is the living image at the end-and the characters' response towards it - that forms the clearest indication of the play's intentions in this respect. Whereas throughout the play the characters engage in a kind of verbal painting, creating mental images by virtual means, in this material image of the Virgin, bearer of God incarnate, the Word in a sense has become flesh. Everaert presents this image as the product of contemplation by the play's main character, as a mystical vision, through which he may ascend to the Trinity. Therefore, I shall expand on the relation between imagination and cognition, as well as meditation.

\footnotetext{
21 Ibid. 53; and Woolgar, The Senses 187.

22 Jaroszýnski P., Beauty and Being: Thomistic Perspectives (Toronto: 2011) 214.

23 Ibid.

24 Brann, The World of the Imagination 59.

25 Grant E., The Nature of Natural Philosophy in the Late Middle Ages (Washington, DC: 2010) 195-196, 201-202, 209.
}

\section{For use by the Author only | (C) 2015 Koninklijke Brill NV}


The mixture of intellectual and spiritual discourse the play offers was characteristic of medieval mysticism. Unlike approaches that suggest an opposition between knowledge and wisdom, defining the first as entirely speculative (based on the mind or reason) and the second as exclusively affective (based on love and good will), placing experience wholly in the realm of the latter, ${ }^{26}$ I would like to argue that natural theology promoted a kind of knowledge equally informed by experience, but primarily of the visible world, which through analogical reasoning was connected-or lifted up-to the invisible realm. Experience on this second, elevated, level may be called sapiential, but it by no means depended on worship, piety and the application of the virtues of faith, hope and charity alone. Cognizing God or any other spiritual entity could involve and combine sapiential as well as natural philosophical knowledge.

Everaert's aspirations in this regard-stimulated by a genre requiring him to establish analogies between a devotional entity and a natural phenomenon-become evident from references ranging from Peter Lombard's Sententiae (Sentences), a classic theological handbook widely known through manuscripts and commentaries, and consulted for disputations and sermons, ${ }^{27}$ to Bernard of Clairvaux's Homiliae super evangelio Missus est angelus Gabriel (Homilies on the Words of the Gospel 'The angel Gabriel was sent'), a popular source of Marian theology highlighting her spiritual significance in the glowing terms that brought Bernard not only the nickname of 'mellifluus [honeysweet voiced] doctor', but also that of 'doctor marialis.' ${ }^{28}$

Everaert testifies to the bottom-up religious interests of late medieval laymen, who paired scientific curiosity with heartfelt devotion, by shifting the object of mystical devotion from God (or Christ) to Mary, the ultimate mediator between heaven and earth; they fostered a distinctive sort of Marian mysticism, utilizing an analogical approach in their efforts to understand her, drawing on and referring to authorities in the realm of both scientia and sapientia. Vernacular drama was one means whereby they strove to secure what

26 Simpson J., "From Reason to Affective Knowledge: Modes of Thought and Poetic Form in Piers Plowman", Medium Aevum 55 (1986) 1-23, esp. 4-6.

27 Ocker Ch., "Scholastic Interpretation of the Bible", in Hauser A.J. - Watson D.F. (eds.) Kaufman S. (ass. ed.), A History of Biblical Interpretation, Vol. 2: The Medieval through the Reformation Periods (Grand Rapids, MI - Cambridge: 2009) 254-279, esp. 255-256; and Van Nieuwenhove R., An introduction to medieval theology (Cambridge: 2012) 147-148.

28 Bell T., Bernardus dixit. Bernardus van Clairvaux in Martin Luthers werken (Ph.D. dissertation, University of Amsterdam, 1989) 296; and Reynolds B.K., Gateway to Heaven. Marian Doctrine and Devotion, Image and Typology in the Patristic and Medieval Periods, Vol. 1: Doctrine and Devotion (Hyde Park, NY: 2012) 215. 
Bernd Hamm succinctly calls immediate or near grace ('nahe Gnade'). ${ }^{29}$ There was a strong need for devotional images to access that grace. This phenomenon partly resulted from what Hamm aptly describes as the dissolution of boundaries ('Entgrenzung') between clerics and laymen. ${ }^{30}$ In the case of the theatre of the rhetoricians, however, this 'democratization' of mystical experience did not lead to simplification and vulgarization. On the contrary, Everaert's play pairs mysticism and intellectualism. And for good reasons, since, as shall be demonstrated below, the mystical process started in the mind or spiritus. Symptomatic of the mystical character of this literature is the fact that references to the Passion and Mary's role as compassionate mother who stood vigil beneath the cross are virtually absent. She is presented not so much as co-sufferer with Christ her son, but as co-redeemer, her heavenly, spiritual significance stressed above her earthly or bodily experience. The inspiration and motivation for imagining her like this lie precisely in the aim of comparing her to light. As we shall see, medieval light metaphysics was firmly grounded in exegetical commentary on the story of creation in Genesis. This tradition offered several opportunities for linking Mary to light's supernatural, cosmological significance as a communicative force between heaven and earth.

I do not wish to claim that Everaert or his fellow rhetoricians had first-hand knowledge of the work or ideas of the authors mentioned and quoted below. Even in those cases where he connects a particular notion to a particular author, Everaert in all likelihood drew on manuscripts and printed books in which these ideas and references were transmitted secondarily — or they were communicated to him by a knowledgeable townsman, maybe a cleric. But in any case it was Everaert who creatively transformed these ideas into a play that demonstrated, within the competitive circumstances of its performance, the high level of intellectual and artistic prowess he and his fellow rhetoricians were capable of achieving. If the jury assessed his plays on the basis of the knowledge and theatrical ingenuity they evinced, Everaert must have met these high standards, since for one comparation he won second prize, for another third prize. But he never came first, and Mary Compared to the Light did not even win a prize. Apparently there were colleagues who wrote even more intellectual, more dramatically sophisticated plays.

\footnotetext{
29 Hamm B., Religiosität im späten Mittelalter. Spannungspole, Neuaufbrüche, Normierungen, ed. R. Friedrich - W. Simon (Tübingen: 2011) 514, 524, 551.

$30 \quad$ Ibid. $440,551$.
} 


\section{Learning by Comparison}

The word 'comparatie' is obviously derived from the Latin comparatio, which, together with the use of auctoritates and exempla, was one of the techniques for setting up the extended argument of a sermon, the so-called dilatatio, with which preachers started after the central theme had been formulated and divisions and subdivisions had been ordered. ${ }^{31}$ Besides a clear definition of the thema, sermon-making included the divisio, the arrangement and consequent discussion of its different aspects or parts. Other principles of composition, easily recognizable in the setup of Everaert's comparations, are the distinctio, 'which is the movement from the general to the particular meanings of a term', and the pluralitatis acceptio, 'which means taking into consideration the different aspects of one element which the distinction or the division had highlighted. ${ }^{32}$ Just as evident is the use of similes, by means of which a particular religious concept or object of devotion, such as Mary, could be categorized both in its whole and in its parts..$^{33}$ Medieval collections of distinctiones contained a large number of such similes, mostly taken from the animal world and from the properties of things, complemented by exempla and Biblical quotations, something which perfectly fits Everaert's approach. Knowledge of the properties of things was considered to enter memory and understanding more easily than logical reasoning and argumentation. ${ }^{34}$

Everaert's comparations also show the influence of sermon-making through the application of so-called natural, figural and scriptural argumentation by means of personifications that embody these different lines of reasoning. ${ }^{35}$ Whereas natural arguments are derived from nature, that is, from natural philosophy, scriptural arguments are obviously from the Bible or from the writings of theological authorities. Figural arguments may either refer to exempla (and literature in general) or to Old Testament references and prefigurations, both in word and image (the latter in the form of tableaux vivants). Scriptural arguments (and images) are sometimes limited to the New Testament, creating a

31 Moser has pointed out the similarities between sermons and Everaert's comparations, particularly in Mary Compared to the Light. See: Moser, "Maria verklaard" 247-248; and idem, De strijd voor rhetorica 140-142.

Serventi S., "Did Giordano da Pisa use the Distinctiones of Nicolas Gorran?", in Andersson R. (ed.), Constructing the Medieval Sermon, Sermo: Studies on Patristic, Medieval, and Reformation Sermons and Preaching 6 (Turnhout: 2007) 83-116, esp. 83.

33 Ibid. 84 .

34 Ibid. $84-85$.

35 Moser, "Maria verklaard" 249-251; and Moser, De strijd voor rhetorica 132-140, 143-146, esp. 135 . 
clear opposition between salvation history sub lege and sub gratia. The application of this threefold approach was, in most instances, explicitly required in the invitations that chambers of rhetoric sent to each other, phrasing the topic of their competitions and stipulating the way it should be dealt with discursively. This must have been the case with the invitations to the competitions for which Everaert wrote his comparations, too, although none has survived.

Generally, Everaert handles every comparation the same way. Two or three discussion partners appear in addition to a mankind character. There is always a personification of Scripture, who most frequently cites the Bible and other authorities, although he or she will not be the only one to do so. ${ }^{36}$ Furthermore, a personification of the comparison itself, of making a typological or moral connection between comparans and comparandum, is included among the regular characters. In Mary Compared to a Ship, the roles are strictly differentiated. First, Clever Pointing (Behendich Voorstel), dressed as a seaman, points out various parts of the vessel, which are then linked to qualities of the Blessed Virgin by Moral Proof (Morael Besouck), dressed as a secular priest, while Scriptural Proof (Scriftuerlicke Beleedinghe), wearing a nun's dress, provides Biblical evidence for each of these connections. Thus, the whole ship, from top to bottom, from back to front, is analyzed in detail—and so, of course, is Mary. Also standard are personifications of the art of rhetoric itself. They can simply be called Rhetoric (Rhetorycka) or may have more sophisticated names such as Rhetorical Pleasure (Rhethoryckelicke Verjolysinghe) or, as in Mary Compared to the Light, Sweet Eloquence. This personification calls attention to the capacities of the art of rhetoric: describing and lauding the object of veneration in an enjoyable, pleasing and also affective, moving way. That, after all, was what rhetoric or rhetorical poetry was supposed to achieve. ${ }^{37}$

\section{Analogy and Cognition}

Setting up analogies, establishing relations or similitudes between material and spiritual objects, was not just an intellectual exercise or game, nor was it just a handy didactic tool for catechetical instruction. However

36 Drewes has pointed to the importance of personifications of Scripture in Everaert's plays. See: Drewes J.B., "Het interpreteren van godsdienstige spelen van zinne", Jaarboek "De Fonteine" 29 (1978-1979) 5-124, esp. 68.

37 That Everaert thought of rhetoric as an art with classical roots is demonstrated by the fact that he describes its personifications on stage as female characters wearing antique clothing, 'à l'antique' ('up zyn antycqe'; above vs. 2). 
entertaining, playful and rhetorically convincing such analogies were deemed to be-a reason certainly for choosing the comparation as a genre for dramatic competition - they essentially were a method of cognition within the preeminent branch of contemporary knowledge, which is to say, theology, and thus formed a serious intellectual endeavour. ${ }^{38}$ The basis of analogical reasoning was Romans 1:20, a passage from Scripture often commented upon: 'Ever since the creation of the world His [God's] invisible nature, namely His eternal power and deity, has been clearly perceived in the things that have been made.. ${ }^{39}$ Another Pauline dictum expressing this idea was 1 Corinthians 13:12: 'But now we see in a mirror dimly, but then face to face'. ${ }^{0}$ Augustine referred to it repeatedly in De Trinitate (On the Trinity). ${ }^{41}$ Cognizing God literally became a form of speculation (speculatio), of mirroring. ${ }^{42}$ Everaert's plays, and those of the rhetoricians with whom he competed, are part of a tradition of natural theology, specifically of the attempt to infer the nature of God (or of any other godly or saintly being, such as the Blessed Virgin) from what could be known about the created world. ${ }^{43}$ The rhetoricians clearly took part in this scholarly endeavour, which is suggested by the use in their texts of such terms as 'experience' ('experientie') and of declinations of 'to speculate' ('speculeren') ${ }_{4}^{44}$ According to Richard of Saint-Victor, not only words but also things were representational and could therefore be analyzed for their spiritual meaning. ${ }^{45}$ Bartholomew the Englishman held the view that man ascended to things

$38 \quad$ Pasnau R., Theories of Cognition in the Later Middle Ages (Cambridge: 1997) 8.

39 Minnis A., "Langland's Ymaginatif and Late-Medieval Theories of Imagination", Comparative Criticism 3 (1981) 71-103, esp. 88; Pasnau, Theories of cognition 9; Cary P., Augustine's Invention of the Inner Self: The Legacy of a Christian Platonist (Oxford: 2000) 65; Newman B., "What Did It Mean to Say 'I saw'? The Clash between Theory and Practice in Medieval Visionary Culture", Speculum 80 (2005) 1-43, esp. 15; MacCormack S., "Augustine on Scripture and the Trinity", in Vessey M. (ed.) - Reid S. (assist. ed.), A Companion to Augustine (Chichester: 2012) 398-415, esp. 405; and Hamburger J.F., "Mysticism and Visuality", in Hollywood - Beckman 2012, Christian Mysticism 277-293, esp. 288.

$40 \quad$ Newman, "What Did It Mean to Say 'I saw'?" 15; Karnes M., Imagination, Meditation, and Cognition in the Middle Ages (Chicago - London: 2011) 18; and MacCormack, "Augustine on Scripture and the Trinity" 405.

41 Augustine, De Trinitate 5.1.1; 6.10.12; extensive references to the mirror-image in 10.3.5; also see MacCormack, "Augustine on Scripture and the Trinity" 405.

42 Hamburger, "Mysticism and Visuality" 288; Milner M., The Senses and the English Reformation (Farnham, Surrey - Burlington, vT: 2011) 73; and Falkenburg R., The Land of Unlikeness: Hieronymus Bosch, The Garden of Earthly Delights (Zwolle: 2011) 117.

43 Pasnau, Theories of Cognition 9.

44 Pleij H., "De laatmiddeleeuwse rederijkersliteratuur als vroeg-humanistische overtuigingskunst", Jaarboek “De Fonteine" 34 (1984) 65-96, esp. 76. Ocker, "Scholastic Interpretation of the Bible" 263-264. 
unseen with the help of things seen. ${ }^{46}$ Part of that visual world was man himself, who was created in God's image (Genesis 1:27; 9:6). ${ }^{47}$ Knowledge about incorporeal realities could be abstracted by comparing (or contrasting) them with corporeal and therefore sensible objects. ${ }^{48}$ Man could learn about God by applying his mental capacities to the natural world around him, and also by reflecting on the workings of the mind itself or of the soul as the mind's seat. It was the place where man could turn from the sensible to the intelligible, from transient to unchanging forms, to use Plato's terms. ${ }^{49}$ There he could find or, better, know God. ${ }^{50}$ He had to turn inward, in order to look upward. ${ }^{51}$

The experiential approach was systematized and most eloquently described by Richard of Saint-Victor in his Benjamin Minor, also called The Book of the Twelve Patriarchs, where he propagated attentive reading in the book of nature as well as in that of Scripture. ${ }^{52}$ Both provided images, likenesses or analogies, from which the intellect could deduce knowledge about divine things. ${ }^{53}$ Indeed, Scripture provided the ultimate example of, and authorization for, the use of image and imagination in cognizing the sacred and divine. According to Richard, the Bible described unseen things through the forms of visible things, thus stimulating comparison. ${ }^{54}$ It impressed the invisible on the memory

46 Minnis, "Langland's Ymaginatif" 88; and idem, "Medieval Imagination and Memory", in Minnis A. - Johnson I. (eds.), The Cambridge History of Literary Criticism, Vol. 2: The Middle Ages (Cambridge: 2005) 237-274, esp. 258.

Augustine, De Trinitate 9.12.17; also see MacCormack, "Augustine on Scripture and the Trinity" 408.

48 Minnis, "Langland's Ymaginatif" 81.

49 Cary, Augustine's Invention 12.

$50 \quad$ Ibid. 54 .

$5^{1}$ Ibid. 39,65 .

52 Minnis, "Langland's Ymaginatif" 88; and Newman, "What Did It Mean to Say 'I saw'?" 15-16.

53 Minnis, "Medieval Imagination and Memory" 256.

54 In this respect Richard drew on Pseudo-Dionysius, who in De coelesti hierarchia linked Scripture to nature by declaring that the former provided similitudes for the latter, in casu for the order of the heavens. See: Ringbom S., "Devotional Images and Imaginative Devotions: Notes on the Place of Art in Late Medieval Private Piety", Gazette des BeauxArts 73 (1969) 159-170, esp. 162; and Minnis, "Medieval Imagination and Memory" 257. Although Pseudo-Dionysius preferred dissimilar to similar likenesses (the former being seemingly contradictory comparisons that unsettled their readers), analogical thinking was dominated by the latter-for example, the analogy of God to light or life, on which, see Minnis, "Medieval Imagination and Memory" 258. The creation of likenesses fits into the via positiva or positive theology: the use of affirmation in thinking about God, on the basis of either speculation or revelation, in the Bible or in nature. See: Minnis, "Langland's Ymaginatif" 89, 92; Brann, The World of the Imagination 59; and Louth A., "Apophatic and Cataphatic Theology", in Hollywood - Beckman, Christian Mysticism 137-146, esp. 137.

\section{For use by the Author only | (C) 2015 Koninklijke Brill NV}


'by the beauty of desirable forms' - a clear reference to the aesthetic meaning of such images and their potential inspiration for artists. ${ }^{55}$ Extended metaphors, clearly the product of imagination, were employed to speculate about-or cognize - spiritual beings or entities, especially in Revelation, as Richard points out. Given Richard's and other authors' appreciation of the literary or, better, imaginative qualities of the Bible, it should come as no surprise that poets and painters not only copied biblical imagery but also felt licensed to employ the mental procedures that had brought about that imagery. ${ }^{56}$ The same idea, that visible things - both in history, that is, Scripture, and the book of nature-led man to invisible things - per visibilia ad invisibilia —inspired Hugh of SaintVictor to produce a detailed account of perception in another treatise, De Operibus trium dierum (On the Works of Three Days), also called Tractatus super invisibilia (Treatise on Invisible Things). ${ }^{57}$ The visible world, more than just the first stage in the mind's ascent to God-one that might as well be skipped by the experienced meditant-became an indispensable, all-consuming phase in this process of elevation. ${ }^{58}$ Moreover, Hugh stressed the beauty of creation and of its creator, turning the study of the visible world into an aesthetic experience. When even mystics had recourse to sense perception, what attraction, we might ask, must it have held for devotionally and intellectually engaged laymen? The visible world lay at their disposal, to be explored through corporeal functions that were like a universal currency.

\section{Vision and Light}

Since man could ascend from things seen to things unseen, vision and light, sight's physical prerequisite, were imbued with great importance. Of the external or bodily senses—-sight, hearing, taste, smell and touch — sight took pride of place, especially in relation to intellection. ${ }^{59}$ Medieval light imagery

55 Benjamin Minor, cap. 15; translation cited in Minnis, "Langland's Ymaginatif" 89.

56 Minnis, "Langland's Ymaginatif" 94.

57 Hamburger, "Mysticism and Visuality" 288.

$5^{8}$ Ibid.; and Poirel D., "The Spirituality and Theology of Beauty in Hugh of St. Victor", in Matter E.A. - Smith L. (eds.), From Knowledge to Beatitude: St. Victor, Twelfth-Century Scholars, and Beyond: Essays in Honor of Grover A. Zinn, Jr. (Notre Dame, IN: 2013) 247-280, esp. 249.

59 Woolgar, The Senses 147-148; Vance E., "Seeing God: Augustine, Sensation, and the Mind's Eye", in Nichols S.G. - Kablitz A. - Calhoun A. (eds.), Rethinking the Medieval Senses: Heritage/Fascinations/Frames (Baltimore: 2008) 13-29, esp. 17; and Milner, The Senses $27-28$. 
originated in Plato's Republic, which posits that knowledge of eternal verities is acquired by a process analogous to vision of the imperfect material world. ${ }^{60}$ It was Augustine who discussed cognition as a way of seeing with eyes that could be impaired — blinded, so to say — by sin or any other defect, and who construed intellectual disability as a disease of the mind's eye that could be cured by education. ${ }^{61}$ Augustine used light analogies to explain the relationship between seeing and understanding, between the outer and the inner eye, between physical and intellectual sight. ${ }^{62}$ Another Church Father, Gregory the Great, spoke of the eyes of the heart or mind-cordis or mentis oculis - as the seat of knowledge about God. ${ }^{63}$ Cognition and understanding, closely linked to the metaphor of eyes that see, also became associated with the action and character of light. Visually impairment was construed as the inability to preceive of light. Likewise, the lack of knowlege was identified with the lack of enlightenment. In the context of medieval views of intellection, the importance of light can hardly be overestimated, because it linked man's intellectual prowess to his divine essence. Commenting on 1 Corinthians 13:12, Augustine described the human mind as an image or reflection of God's nature. ${ }^{64}$ Mankind, in its effort to know, was closely likened to God. ${ }^{65}$ In comparable words, Thomas Aquinas in his Summa Theologiae (Summary of Theology) explained that 'the intellectual light in us is nothing other than a particular shared likeness of the uncreated light', ${ }^{6} 6$ that is, of God. Robert Grosseteste, a medieval champion of optics, called illumination the force by which God filled the emptiness of the rational part of the mind. ${ }^{67}$

6o $\quad$ Lindberg D.C., Theories of Vision from Al-Kindi to Kepler (Chicago - London: 1976) 95; and Tachau K.H., Vision and Certitude in the Age of Ockham: Optics, Epistemology and the Foundations of Semantics 1250-1345 (Leiden: 1988) 6-8.

61 Cary, Augustine's Invention 41, 74-75.

62 Gilson S.A., Medieval Optics and Theories of Light in the Works of Dante, Studies in Italian Literature 8 (Lewiston etc.: 2000) 224-225.

63 Fraeters V., "Visio/Vision", in Hollywood - Beckman, Christian Mysticism 178-188, esp. 179; and Williamson, "Sensory Experience in Medieval Devotion" 12-13.

64 Augustine, De Trinitate 15.23.44; also see Karnes, Imagination, Meditation, and Cognition 18; and Schumacher, Divine Illumination 34 .

65 Karnes, Imagination, Meditation, and Cognition 13.

66 Aquinas Thomas, Summa Theologiae I, Q. 85, Art. 5; translation cited in Pasnau, Theories of Cognition 9 .

67 Grosseteste Robert, On the Six Days of Creation: A Translation of the Hexaëmeron, ed. C.F.J. Martin (Oxford: 1996) 78, 8 o. 
The idea of the visible world being a mirror of the invisible world stimulated speculation in the sense of intellectual reflection on light too, it being the most visible of all natural phenomena and the force that made things visible in the first place. ${ }^{68}$ Its reflective potential, the possibilities it offered for drawing analogies between things material and spiritual, was used to help understand and express the meaning of the highest of elements in this realm: God, the Trinity, heaven and its inhabitants, man in his spiritual and intellectual dimensions. The link between light and intellection led to representations of theology as a queen sparkling and shining in the light of divine wisdom. ${ }^{69}$ Its sister discipline of philosophy was called the lignum scientiae boni et mali ('the light of knowledge about right and wrong'), subject to the light of revelation. ${ }^{70}$ Theologians were stimulated to construct analogies between natural light and divine light. ${ }^{71}$

In De moribus Ecclesiae Catholicae (On the Morals of the Catholic Church), Augustine described man's knowledge of God as 'being inwardly illuminated' by Him, since 'He is light itself' and 'it is given to us to be illuminated by that light'.72 And so, he continues, 'when the soul tries to fix its gaze upon that light, it quivers in its weakness and is not quite able to do so. Yet it is from this light that the soul understands whatever it is able to understand. ${ }^{73}$ Consequently, Augustine considered light to be the essence of Christ as well. ${ }^{74}$ His words are taken from De Genesi ad litteram (On the Literal Meaning of Genesis), wherein he discusses the creation of light and the light of creation. (As we shall see, in his play Everaert too refers to this primordial light.) In Augustine's case, as in many others, the main source for these light analogies was Scripture. The Bible frequently employs light imagery to express the essence of a number of ideas and feelings: life, salvation, judgment, truth, delight, joy. ${ }^{75} \mathrm{~A}$ blinding, bright

68 Hedwig, Sphaera Lucis 62; and Gilson, Medieval Optics 177.

69 Hedwig, Sphaera Lucis 80, 164.

$70 \quad$ Ibid. 165 .

71 Gilson, Medieval Optics 230 and n. 22.

72 Augustine, De moribus Ecclesiae 1.11.19; translation cited in Gill M.J., "Augustine's Light", Allegorica 23 (2002) 32-54, esp. 37. Also see Gilson, Medieval Optics 231-232; Matthews G.B., "Knowledge and illumination", in Stump E. - Kretzmann N. (eds.), The Cambridge Companion to Augustine (Cambridge: 2001) 171-185, esp. 179-181, 183; and Karnes, Imagination, Meditation, and Cognition 37, 73-74.

73 Augustine, De Genesi ad litteram 12.31.50; translation cited in Matthews, "Knowledge and illumination" 180.

74 Augustine, De Genesi ad Litteram 4.28; also see Böhme G. - Böhme H., Feuer, Wasser, Erde, Luft. Eine Kulturgeschichte der Elementen (Munich: 1996) 156.

75 Schumacher, Divine Illumination $54,58$. 
light was considered a manifestation of the divine.${ }^{76}$ Christ even calls Himself the light of the world (John 8:12). ${ }^{77}$ In fact, the essential role attributed to it in the story of creation stimulated the use of light terminology to express and explain the meaning of all existence, visible and invisible. ${ }^{78}$

Since sensory, corporeal vision involves physical light, illumination as Augustine used it is not to be taken as exclusively metaphorical. The scientific study of the physics of light-optics - was essential to the cognition of God, and played a crucial role in 'divine science', to use Thomas Aquinas's terminology. ${ }^{79}$ Corporeal vision was not only a step in the process leading to spiritual vision; it could easily be conflated with it, the one leading almost imperceptibly to the other, to such an extent that the two become virtually identical. ${ }^{80}$ This was especially true for objects that were thought to be sacred and to have a sacramental effect. Thus, corporeal sight became spirit-aided, illuminated sight. The light that, according to the extra-missive model of corporeal vision, left the eye to encounter its object, could easily be seen as the light that Augustine called God. This dominant optical theory of corporeal vision - which posited that the soul emits rays of light through the eyes, and, that having struck the perceived object, these same rays carry its shape and color back through the eyes to the soul ${ }^{81}$ — provided a ready analogy for supernatural vision. ${ }^{82}$

In fact, Augustine devised a scheme consisting of three levels of vision or meditation that help man to complete the trajectory from scientia to sapientia: he calls the first one corporeal (corporalis), the middle one imaginative or spiritual (spiritualis), and the third one intellectual (intellectualis). ${ }^{83}$ The

\section{Woolgar, The Senses 151.}

77 Böhme - Böhme, Feuer, Wasser, Erde, Luft 149.

78 Hedwig, Sphaera Lucis 196-197.

79 Aquinas Thomas, The Division and Methods of the Sciences: Questions V and VI of his Commentary on the De Trinitate of Boethius, ed. and trans. A. Maurer (Toronto: 1963) 8; Lindberg, Theories of Vision 99; Hahn C., "Visio Dei: Changes in Medieval Visuality", in Nelson R.S. (ed.), Visuality before and beyond the Renaissance: Seeing as Others Saw (Cambridge: 2000) 169-196, esp. 174.

$80 \quad$ Lindberg, Theories of Vision 95; and Hahn, "Visio Dei" 175.

81 Lindberg, Theories of Vision 91; Hedwig, Sphaera Lucis 206, 223-224; and Woolgar, The Senses 21-22, 148.

82 Vance, "Seeing God" 23.

83 De Genesiad litteram 12.24.51, passim; and De Trinitate 11.1-3. Also see Ringbom, "Devotional Images and Imaginative Devotions" 162; Minnis, "Langland's Ymaginatif" 92-93; Brann, The World of the Imagination 53; Hahn, "Visio Dei" 171; Matthews, "Knowledge and illumination" 175-176; Gill, "Augustine's Light" 35-36; McGinn B., "Visions and Visualizations

\section{For use by the Author only | (C) 2015 Koninklijke Brill NV}


middle one clearly involves the use of interior images. That spiritual vision was also called imaginative vision, can be explained by a passage from Thomas Aquinas's Summa Theologiae: 'In the present life, enlightenment by the divine ray does not occur without the veil of phantasms, because it is unnatural to man, in his present state of life, to understand without a phantasm': ${ }^{84}$ The third level of vision provided a platform for the ultimate goal of mystical ascent: the seeing of God, or visio Dei, the 'exalting instant of restored mimesis - that [connects] the seer to the Seen' in man's soul. ${ }^{85}$ Despite its ideal of imageless devotion, vision and light played a significant role in the mystical movement as well. Descriptions of mystical experiences such as lumen gloriae or visio Dei already point in this direction. ${ }^{86}$ As corporeal sight supposed that one uses one's eyes and will to see, so, according to the mystic Jan van Ruusbroec, did spiritual sight suppose that one sees the light of grace, approaching it with a clean conscience and good will. Man's will was expected to catch a spark of the divine light and fan it into flame. ${ }^{87}$

\section{Imagination}

Thomas's use of the word phantasma - image - brings us to a more detailed discussion of the faculty of imagination, one of the so-called internal senses, as opposed to the external or bodily senses, of which, as noted above, sight was deemed the most important. ${ }^{88}$ Having been impressed on the mind, the

in the Here and Hereafter", Harvard Theological Review 98 (2005) 227-246, esp. 230; Minnis, "Medieval Imagination and Memory" 245-256; Newman, "What Did It Mean to Say 'I saw'?" 6-7; Rothstein, Sight and Spirituality 12; Karnes, Imagination, Meditation, and Cognition 6; and Fraeters, "Visio/Vision" 178.

84 Summa Theologiae, II-II, Q. 174, Art. 2. Also see Ringbom, "Devotional Images and Imaginative Devotions" 162; Minnis, "Langland's Ymaginatif" 81 and n. 81; and Brann, The World of the Imagination 59. On Thomas's ideas about imagination, see ibid. 62-64.

85 Vance, "Seeing God" 25.

86 Hedwig, Sphaera Lucis 236.

$87 \quad$ Ibid. $25^{-2}-25^{2}$.

88 Their number, name, location and function varies. See: Steneck N.H., "Albert de Great on the Classification and Localization of the Internal Senses", Isis 65 (1974) 193-211, passim; Kaulbach E.N., "The 'Vis Imaginativa' and the Reasoning of Ymaginatif in the B-Text of 'Piers Plowman'", The Journal of English and Germanic Philology 84 (1985) 16-29, esp. 27; and idem, "The 'Vis Imaginativa secundum Avicennam' and the Naturally Prophetic Powers of Ymaginatif in the B-Text of 'Piers Plowman', The Journal of English and Germanic Philology 86 (1987) 496-514, esp. 502-503. 
mental images of an external object, called species or similitudes, ${ }^{89}$ were then converted by the interior senses into more complex representations, from which, eventually, the intellect distilled universal concepts, thus creating abstract thought. ${ }^{90}$

In Everaert's play, representation of and reference to the phenomenon light involves imagination, which was seen to facilitate the cognitive use of mental images. ${ }^{91}$ Essential for understanding the nature of imagination was its position between corporeal sense and abstract reason, where it functioned as the linchpin, so to speak, between perception and understanding. ${ }^{92}$ Out of sensations imagination formed mental pictures, which were handed over to reason and abstracted into ideas, which in turn were stored in memory, together with the sensory and mental images whence they were derived. From there they could be retrieved and once again subjected to the operation of the faculty ${ }^{93}$ Of course, like sight, the sense it so strongly depended on, imagination could be criticized for the exaggeration, distortion and delusion it sometimes produced. Even authorities who otherwise underlined its positive potential warned against the vain thoughts it could provoke, ${ }^{94}$ not to speak, of course, of the outright condemnation it later received in Protestant circles during the sixteenth century. ${ }^{95}$ Nevertheless, it was generally considered to be a positive, reliable means of knowledge acquisition. ${ }^{96}$

89 Brann, The World of the Imagination 58; Pasnau, Theories of Cognition 14; and Hatfield G., "The Cognitive Faculties", in Garber D. - Ayers M. (eds.), The Cambridge History of Seventeenth-century Philosophy (Cambridge: 2003) 951-1002, esp. 957.

90 Pasnau, Theories of Cognition 13, 52, 56; Karnes, Imagination, Meditation, and Cognition 25, $3^{6-38}, 43,50-51,54-55,57-58$; and Schumacher, Divine Illumination 93.

91 For the purpose of this article it is unnecessary to distinguish, as some medieval theorists did, between imaginatio as the internal sense proper, located in the brain, and vis (or virtus) imaginativa as the reasoning faculty operative within that sense organ or location (Kaulbach, "The 'Vis Imaginativa'" 20-21), nor between imaginatio and phantasia as different internal senses, as was also done (Steneck, "Albert de Great" 197-198, 201-202; Minnis, "Langland's Ymaginatif" 72-73; and Simpson, "From Reason to Affective Knowledge" 7).

92 Simpson J., "The Rule of Medieval Imagination", in Dimnick - Simpson - Zeeman, Images, Idolatry, and Iconoclasm 4-24, esp. 10; Vance, "Seeing God" 23-24; and Karnes, Imagination, Meditation, and Cognition 4.

93 Minnis, "Langland's Ymaginatif" 72, 74.

94 Kaulbach, "The 'Vis Imaginativa'" 17, 25; Woolgar, The Senses 16-17; and Vance, "Seeing God" 24-25.

95 Simpson, "The Rule of Medieval Imagination" 11, passim.

96 Karnes, Imagination, Meditation, and Cognition 7; and Schumacher, Divine Illumination 59. 
As a cognitive tool, imagination (phantasia in Greek) was defined by Aristotle in De anima (On the Soul). ${ }^{97}$ The Latin term imaginatio was coined by Augustine in one of his Epistulae (Letters). ${ }^{98}$ This faculty not only had the ability to create images - phantasiae - of things seen, but also of things unseen, by combining elements of objects visually perceived, and it enabled speculation about the course of invisible (spiritual) or future events and the actions and appearances of the beings featured in them. ${ }^{99}$

The mental representations so essential to the cognitive process, were described by Thomas Aquinas as likenesses (similitudes). ${ }^{100}$ Although he did not conceive of such likenesses as necessarily iconic, ${ }^{101}$ most medieval authors describing the workings of the mind-on whatever level of sophisticationdid so in terms of image and image-making. The greatest of authorities (in Thomas's estimation) had taken this position. In De anima, Aristotle stated that ' $[t]$ he soul never thinks without an image.'102 Thomas brought Aristotle's views on cognition into conversation with Augustine's, and tried to reconcile them. ${ }^{103}$ In De Trinitate the latter had observed that 'we think in terms of images of what we have experienced.' ${ }^{104}$ Elsewhere he stressed that the mind always relies on images. ${ }^{105}$ Imagination retained the sensible forms received by the five senses and made these forms available to the intellect. ${ }^{106}$ In his Confessiones (Confessions) he argued that man uses his reasoning power to see 'intellectually Your [God's] "invisible things, by means of the things that

97 Aristotle, De Anima III.3, 428a1-2, 428a12; III7, 431b5-6; and Karnes, Imagination, Meditation, and Cognition $32-33$.

98 Augustine, Epistulae 7.3.6; Minnis, "Medieval Imagination and Memory" 241; and Karnes, Imagination, Meditation, and Cognition 5.

99 Minnis, "Langland's Ymaginatif" 73, 76; Carruthers M., "Imaginatif, Memoria, and "The Need for Critical Theory' in Piers Plowman Studies", The Yearbook of Langland Studies 9 (1995) 103-120, esp. 105; Pasnau, Theories of Cognition 128; Minnis, "Medieval Imagination and Memory" 242; and Karnes, Imagination, Meditation, and Cognition 6-7.

100 Pasnau, Theories of Cognition 87.

101 Ibid. 108.

102 Aristotle, De anima III.7, 431a16-17; Brann, The World of the Imagination 44; Kay S., The Place of Thought: The Complexity of One in Late Medieval French Didactic Poetry (Philadelphia: 2007) 4; and Karnes, Imagination, Meditation, and Cognition 3, 36.

103 Pasnau, Theories of Cognition 10. Also see Schumacher, Divine Illumination 165-179.

104 Augustine, De Trinitate 8.5.7; Carruthers, "Imaginatif, Memoria" 107; and MacCormack, "Augustine on Scripture and the Trinity" 404.

105 Karnes, Imagination, Meditation, and Cognition 18.

106 Gilson, Medieval Optics 93. 
are made", a reference to Romans 1:20, cited above. ${ }^{107}$ In other words, imagemaking was a 'cognitive necessity'.108 Human reason simply had to be led by likeness, analogy or comparison of what could be perceived. Hence, too, the use of metaphors, symbols, parables and exempla. ${ }^{109}$ Thomas Aquinas expressed the same idea as follows: '[S]imple and spiritual impressions easily slip from the mind, unless they be tied as it were to some corporeal image, because human knowledge has a greater hold on sensible objects.'110 It was man's imagination, his associative faculty, so to speak, ${ }^{111}$ that produced these images.

The role of imagination in natural philosophy should not be underestimated.112 Since knowledge of the visual world played a significant role in theology as well, imagination had an equally important role to play in cognizing divine things. Thomas Aquinas dealt with cognition, as it pertains to theology, in questions five and six of his Expositio super librum Boethii De Trinitate (Exposition on Boethius's Book On the Trinity). He too referred to Romans 1:20 to argue that theology was about natural, visual things as they refer to first or divine principles. ${ }^{113}$ As the divine science was nowhere more appropriately taught than in Scripture, and Scripture described divine things 'under sensible figures', one had to rely on images and imagination when practicing theology:114 '[A]ll our knowledge begins in the sense.'115

\section{Scientia and Sapientia}

As noted above, the careful perception or observation of the natural world could yield insights into the character, workings and meaning of spiritual beings and entities. But mental images or pictures did more: they regulated ethical conduct and stimulated affective piety. ${ }^{116}$ The link between cognition

\footnotetext{
107 Augustine, Confessions 7.23; Cary, Augustine's Invention 65; Minnis, "Medieval imagination and memory" 240.

108 Carruthers, "Imaginatif, Memoria" 104.

109 Minnis, "Langland's Ymaginatif" 84; and Simpson, "From Reason to Affective Knowledge" 8.

110 Thomas Aquinas, Summa Theologiae II-II, Q. 49, Art. 1; and Minnis, "Langland's Ymaginatif", 9o, esp. n. 67 .

111 Karnes, Imagination, Meditation, and Cognition 7.

112 Grant, The Nature of Natural Philosophy 164-165, 171-172, 192-193.

113 Aquinas, The Division and Methods of the Sciences 39, 44, 67.

114 Ibid. 67.

115 Ibid. 68.

116 Minnis, "Medieval Imagination and Memory" 240.
} 
and affection is characteristic of mysticism. ${ }^{117}$ Indeed, scholars stress the intimate connection between natural philosophy and devotional literature, since both relied on mental images. ${ }^{118}$ Imagination as analogical reasoning led man to the point where mystical contemplation begins, ideally leading to union with God. ${ }^{119}$ Thus, the mystical process, even the union itself, involved a kind of knowing on the part of the meditant, ${ }^{120}$ which to a certain extent could be called intellectual or rational, that is, up to the point where, to quote William of Saint-Thierry, 'reason passes into love and is transformed into a certain spiritual and divine understanding which transcends and absorbs all reason.'121 The idea of reason being consumed by love (or affection) was widespread and also adopted by mystical thinkers such as Bernard of Clairvaux and Bonaventure. ${ }^{122}$ In terms of the Augustinian triad of vision, this meant that man, after passing the first two levels of corporeal and imaginative sight, depended on divine illumination - light in a metaphorical sense - to reach the third level of intellectual sight or understanding, ${ }^{123}$ that is, illumination as a response to love and good will, leading to the kind of understanding that was called sapiential in the context of mysticism. According to Richard of Saint-Victor, this level of understanding even went beyond the mind: excessus mentis. ${ }^{124}$

To arrive at an understanding of God or Christ, man, according to Augustine, depended on the constant presence of divine light. ${ }^{125}$ But however much affective theology may be associated with Augustine, ${ }^{126}$ the role he attributed to imagination implied and stimulated this faculty's application in both rational and affective knowledge, the former leading to the latter. ${ }^{127}$ In fact, he primarily used vision or sight as equivalents for intellection and cognition. As he writes in De Trinitate: 'nothing can be loved before first being known'.128

117 McGinn B., "Love, Knowledge, and Mystical Union in Western Christianity: Twelfth to Sixteenth Centuries", Church History 56 (1987) 7-24, esp. 21; and Karnes, Imagination, Meditation, and Cognition 15-16.

118 Karnes, Imagination, Meditation, and Cognition 11.

119 Ibid. 5 .

120 McGinn, "Love, Knowledge, and Mystical Union" 9.

121 Translation cited ibid. 10.

122 Ibid., passim.

123 Gill, “Augustine's Light” 37, esp. n. 15; Karnes, Imagination, Meditation, and Cognition 69; Schumacher, Divine Illumination 141-142; and McCormack, "Augustine on Scripture and the Trinity" 406-407.

124 Fraeters, "Visio/Vision" 181.

125 Karnes, Imagination, Meditation, and Cognition 71.

126 Simpson, "From Reason to Affective Knowledge" 5 .

127 MacCormack, "Augustine on Scripture and the Trinity" 407.

128 Augustine, De Trinitate 10.1.2; and Karnes, Imagination, Meditation, and Cognition 18. 
Lovingly imagining God or Christ was essentially the same as cognizing Him. ${ }^{129}$ For Bonaventure, too, meditation was cognitive as well as affective; it meant to love and to know God at the same time. ${ }^{130}$

The use of imagination in devotional life or meditation implied 'an experiential route' to God. ${ }^{131}$ It led to what Sixten Ringbom calls 'imaginative devotions' or 'imaginative visions.'. ${ }^{132}$ Unlike miraculous visions, that is, apparitions in the strict sense, such 'imaginative visions' were created by the reproductive imagination, either by looking at material images — sculpted, painted, printed —or by reading descriptions of figures or scenes of a devotional kind, or of visions in the strict sense, or by retrieving such images from memory. One might add that in devotional art and literature these mental images materialized in sensually perceivable representations. Despite their aim of imageless devotion, the 'spiritual elite', as Ringbom calls the mystics, could not and did not do without corporeal and spiritual images, thus implementing the Augustinian triad. ${ }^{133}$ His claim is that during the late Middle Ages the practice of such 'imaginative devotions', stimulated by material imagery, extended beyond the realm of convent and cloister, and became part of lay religious practice as well. ${ }^{134}$ With the help of images and imagination, they too started to aim for the visio Dei.

The passing reference above to visions in the strict sense needs to be followed up with an explanation of the distinction drawn between visions that resulted from the meditant's active imagination and visions that were passively received from outside, supernaturally. These visions proper were situated within the realm of dreams. A further distinction was made between the enigmatic dream (somnium) and the prophetic vision (visio). This sort of mental imagery was highly valued in mystical circles as a means of gaining insight into spiritual matters, ${ }^{135}$ but they were non-experiential, in the sense that they did not have a basis — at least not in theory — in the meditant's visual memory, in images based on sense perception, either external or internal. However, once experienced, such visions could become part of visual memory and of the operations of imagination as well. In fact, being an instrument of the Holy Spirit, Scripture contained many descriptions of persons receiving

\footnotetext{
129 Karnes, Imagination, Meditation, and Cognition 75.

130 Ibid. 112.

131 Cary, Augustine's Invention 71.

132 Ringbom, "Devotional Images and Imaginative Devotions" 162, 166; Harbison C., "Visions and Meditations in Early Flemish Painting”, Simiolus 15 (1985) 87-118, esp. 102-103, 106107; and Rothstein, Sight and Spirituality 39.

133 Ringbom, "Devotional Images and Imaginative Devotions" 157, 164; Harbison, "Visions and Meditations" 113-114; and Rothstein, Sight and Spirituality 71-72.

134 Ringbom, "Devotional Images and Imaginative Devotions" 164-166.

135 Minnis, "Medieval Imagination and Memory" 244.
} 
such images-Revelation was a genuine storehouse of them-which through reading, writing and visual representation became available to large audiences of believers.

I am concerned here neither with discussions about the exact nature of this beatific vision-directly or through theophany-nor with the way late medieval mystics broke loose from the Augustinian triad and mixed its consecutive levels. ${ }^{136}$ What is important in the context of Everaert's play is that medieval mysticism tended towards experience, which depended 'both in reception and expression on the subject's power of imaginative seeing,'137 on the ability mentally to visualize the object of contemplation, by meditating on verbal and visual imagery of a devotional kind provided by texts and representations in sculpture, painting and print, and, as far as this meditative process was subsequently described or depicted, on the ability to employ such imagery. Scholars define this kind of meditation as 'experiential hermeneutics' or 'imaginative theology'.138 Thus, knowing (or seeing) God or any other spiritual being involved the employment of both material and mental images in a systematic, step-by-step process of reasoning. ${ }^{139}$

\section{Discursing Light}

In a relatively long prologue (195 lines from a total of 738 ) the audience of Mary Compared to the Light is informed clearly about the perceptual and cognitive issues involved in the upcoming comparison. Experiential Proof and Sweet Eloquence have just announced the play's topic: to compare Mary to light and truly to understand this comparison are virtually beyond man's mental capacities; they thus indicating the ambitiousness of the journey upon which they are about to embark. Shortly thereafter, Imaginative Mind enters the playing area, making his way through the audience, while he recites a roundel ('rondeau' in French, 'rondeel' in Dutch) calling on Mary to grant him her grace. (He might as well be begging for alms.) The two characters already on stage order him to shut up, since he is hindering the audience from hearing the play. When he notices that they are going to compare Mary to light, he demonstrates his initial ignorance by wrongly interpreting the word 'claerheyt' ('clarity') to mean

136 McGinn "Visions and Visualizations" 233-234, 238; and Fraeters, "Visio/Vision" 180-187.

137 McGinn, "Visions and Visualizations" 235.

138 Fraeters, "Visio/Vision" 185.

139 Hahn, "Visio Dei" 169, 177-183; and Gill, “Augustine's Light" 38-39. 
(the sound of) a trumpet and then (the scent and taste of) wine. ${ }^{140}$ The word 'claerheyt' indeed is unisonous with 'clareit', a popular wine spiced with herbs. And a high-pitched trumpet might have been known by the term 'claerheyt' (or a homophone) as well. Despite or, perhaps better, thanks to his misinterpretations of the word 'claerheyt', Imaginative Mind is able to demonstrate how keenly developed his senses of hearing, smell and taste are. His reminiscences about the occasions when he registered the sound of that trumpet (on the feast of the Holy Blood in Bruges ${ }^{141}$ ) and heard the name of that wine, smelled and tasted it, show how much his mind is prone to imagination, to making analogies—or images—in order to express the impressions these perceptions made on his mind. Therefore it is no surprise that he shows great eagerness to learn about and imaginatively to visualize the clarity of light, especially after hearing that it will be compared to Mary, of whom he shows himself a fervent devotee. When Experiential Proof responds that he does not command all five senses, he stresses that he hears, touches, smells and tastes as well as anyone else. ${ }^{142} \mathrm{He}$ challenges his discussants, asking rhetorically: 'Do I not have command of all my senses, as I should have / just as much as you, as can clearly be noted?'.143 Although, Sweet Eloquence avows that he lacks the uppermost sense, and will therefore be unable 'to reach an exact understanding of light', ${ }^{144}$ they nevertheless lift him onto the stage. ${ }^{145}$ Apparently this character is deemed capable of compensating for his visual disability.

Once on stage, Imaginative Mind almost immediately takes the initiative by posing the first question to the triumvirate of discussants, which by now has been joined by Grounded Scripture. ${ }^{146}$ He implores the latter to uncover the essence of the comparison between Mary and light. When Grounded Scripture asks him to identify himself, he answers:

\footnotetext{
140 Vss. 45-48; vss. 61b-66.

141 On this feast and its celebration in Bruges, see Brown A., Civic Ceremony and Religion in Medieval Bruges c. 1300-1520 (Cambridge: 2011), passim.

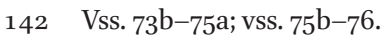

143 Vss. 79-80: 'Hebbic myn zinnen niet, naer den betaeme, / alzo wel als ghy by sulcker bekenthede?'.

144 Vs. 84: 'van de claerheyt te begryppene trechte verstant'.

145 Vs. 94 .

146 When she enters the stage, she is recognized by Imaginative Mind first, who speaks the line: 'I have seen her, that noble woman' ('Ic hebbese ghesien, de vrauwe weert'; vs. 100). It seems Everaert mistakenly put these words in the mouth of Imaginative Mind. Given the pattern of speech alternation, it seems more likely that it was Experiential Proof's turn to utter these words.
} 
Imaginative Mind:

to learn, without any limitation,

with what clarity you intend

to praise Mary this very moment,

to what you wish to equate her through comparison:

Is there more than one [clarity] within the created world? ${ }^{147}$

The lines following the mention of his name seem intended to exemplify its meaning. Imaginative Mind wants to use his mind's imagination to learn about this intriguing comparison between Mary and light. In the last line he formulates his first question, urging his advisors to define the exact kind of clarity to which they are going to compare Mary. They mention the clarity (or light) of fire, of the moon and stars, of dawn and dusk, of shining gems, of lightning, even the clarity (because of their purity) of distilled or sieved substances, such as water, gold and silver. Bright-sounding instruments may be called clear as well. ${ }^{148}$ But their enterprise centers on none these clarities. Rather, it is the 'perfect clarity' ('vulmaecte claerheyt'), later called the 'clarity above all clarities' ('claerheyt boven all claerheden'), that they firstly wish to cognize, the clarity to which all other clarities are subordinate. ${ }^{49}$ This 'claerheyt' is nothing less than the primordial light created by God on the first day of creation (Genesis 1:3). Mary should be compared to it, for all other species of light or clarity to be discussed in the play are derived from this first light. Out of this primordial light came forth the light of the sun (Genesis 1:4), which Grounded Scripture compares to Christ. Thus, before the play proper has even formally begun, Mary is closely associated with creation, incarnation and salvation. So too, at the prologue's end, her spiritual significance will be exemplified by the unveiling of a tableau vivant of Queen Esther kneeling before Ahasuerusthe Old Testament type for Mary's position as intercessor in heaven. It is in this context that all that follows should be understood. Sweet Eloquence announces that she, together with Experiential Proof and Grounded Scripture, will explain 'the properties of light' ('de condicien des claerheyts'), ${ }^{150}$ and

147 Vss. 12ob-125: 'Ymagineirlic Gheest: / Om te wetene, zonder vercleenynghe, / van wat claerheyt dat ghy meenynghe / Maria te loven hebt te deser spacien, / daer ghy huer by ghelycken wilt met comparacien: / esser meer dan een binnen sweerelts bestiere?'.

148 Vss. 126-139.

149 Vss. 141-142, 206.

150 Vs. 201. 
Imaginative Mind declares that he shall apply his imagination in an effort to understand this light: 'My Imaginative Mind yearns for it', he says. ${ }^{151}$

As already noted, Eveaert's play consists of a series of discursive exchangesnineteen to be precise-devoted to the various aspects of the comparison, in which the characters take turns according to a regular pattern. From the moment the prologue ends and the actual comparation starts, the clauses of the four characters alternate in near flawless rhythm. Of the nineteen sequences, each devoted to one aspect of the analogy, thirteen are triggered by Imaginative Mind, who either asks his discussants to expand on a natural property or effect of light, or offers praise to Mary (often in the form of a rhetorical question), referring to a particular characteristic that inspires another analogy. In a number of instances, a single word voiced by Imaginative Mind gets the other characters going. Sometimes even a correspondence in sound-through rhyme - does the trick. For example, the concluding line of one of Imaginative Mind's speeches-'Int hooren en can icx niet worden versadich' ('In hearing I cannot get enough')—provokes Experiential Proof to start his speech with the line, 'De claerheyt es een zuver wesen ghestadich' ('Light is a pure and constant entity'), in which 'versadich' ('enough') rhymes with 'ghestadich' ('constant'). Thus cued, Experiential Proof begins to expand on the brightness of light. ${ }^{152}$ He always speaks first, putting forward his scientific observations, after which Sweet Eloquence, in a heightened tone, links these observations to Mary's redemptive powers. Grounded Scripture follows, elaborating upon Sweet Eloquence's panegyric lines with theological references and citations. Occasionally, at the end of a sequence, Sweet Eloquence adds yet another clause. ${ }^{153}$ Sometimes, halfway through a sequence, Experiential Proof speaks a second time in order to clarify a particular point of his scientific explanation. ${ }^{154}$ Even in those instances when Imaginative Mind starts a sequence by asking his discussants to explain some aspect of Mary's spiritual significance instead of a property of natural light, Experiential Proof responds by describing the tertium comparationis, the abundance of light for example, in physical terms, after which Sweet Eloquence and Grounded Scripture connect this shared element with Mary, in casu with the abundant grace she obtains for mankind through intercession with God or Christ.

The nineteen sequences are devoted to the following analogies: 1) just as light enables man to distinguish between objects situated high above, in the

\footnotetext{
151 Vs. 202: 'Myn Ymagineirlic Gheest daernaer haect'.

152 Vss. 504-505.

153 Vss. 557-568, 599-604.

154 Vss. 651-653a.
} 
middle and below, so too Mary, thanks to her intermediate position, helps man to distinguish between heaven and earth; 2) just as light by its purity enables man to see his actions and their effects, so too God made Mary stand out in purity so that through her He could effect our salvation; 3 ) just as light is unsurpassed in beauty, so too Mary is more beautiful than anything else; 4) just as light causes enchantment and vitality in nature, so too Mary enchants and enlivens every sort of man, whatever their condition on earth or in the hereafter; 5 ) just as the splendor and glory of light adorns everything upon which it shines, so too Mary's glory enlightens all heaven; 6) just as light shines on everyone and everything, so too Mary brings help and comfort to all; 7) just as the unchanging power of light is not felt everywhere with the same intensity because it is sometimes blocked, so too Mary's grace is unceasing, but does not touch everyone because of sin; 8) just as the velocity of light is higher than man can conceive, so too Mary immediately arrives whenever and wherever one prays for her help; 9) just as light penetrates even the tiniest aperture as soon as it shines, so too Mary enters the sinner's heart, however slight his cry; 10) just as light illuminates even the most secret places of man's body, so too Mary reaches into the deepest corners of man's mind; 11) just as the purity of light is unstained by the matter it touches and rather than staining matter, purifies it, so too Mary is unstained by the sins of those to whose rescue she comes, and instead delivers them from sin; 12) just as it is impossible for light and darkness to coincide, for the former inevitably casts out the latter, so too Mary's clarity expels the gloom of sin; 13) just as light is known to be good and noble in effect, so too Mary has an ennobling effect on mankind; 14) just as light is constant, whichever way the wind blows, so too Mary stood firm in the face of all adversity, and therefore was chosen by God to bear His son; 15) as light is abundant and rebounds from the surfaces it strikes, so Mary shines abundantly within the heart of man, her light refracted through the performance of good deeds, which serve as an example to sinners; 16) just as light makes plants grow and thus produces food, so too Mary brings the food of comfort; 17) just as light directs the paths of man and prevents him from straying, so too Mary leads man away from original sin, the heritage of Adam and Eve's disobedience; 18) just as light descends or emanates from air (like heat from fire and scent from herbs), and yet remains separable, so too Mary closely relates to the Trinity without becoming part of it; 19) just as the light of the highest air or sphere enables man to discover the secrets of the stars, so too Mary enables man to understand the secrets of the Trinity. ${ }^{155}$

155 1) vss. $215^{-230}$;) vss. 231-242; 3) vss. 243-258; 4) vss. 259-281a; 5) vss. 281b-292; 6) vss. $293-316$; 7) vss. $317-355$ a; 8) vss. $355^{b-382 ; 9)}$ vss. $383^{-394 ; ~ 10) ~ v s s . ~} 395^{-402 ; 11) ~ v s s . ~ 403-~}$ 
Thus, Imaginative Mind's questions about the natural aspects of light (most of which he cannot see) are answered or, better, internally illumined, with the help of his imagination, by reference to supernatural characteristics of the Blessed Virgin, and, vice versa, her supernatural characteristics are explained through reference to the natural aspects of light. At this stage, both for him and for the audience, all discourse is conducted verbally and aurally. Imaginative Mind uses verbs such as 'segghen' ('to speak'), 'berechten' ('to teach with words'), 'vermonden' ('to put into words') and 'horen' ('to hear') to describe the kind of communication and reception taking place on stage. ${ }^{156}$ Judging from his reactions, the analogies do not only have a rational effect on him. The more he learns about the correspondence between Mary and light, thus gradually exploring the spiritual meaning of the Blessed Virgin, the more exalted he becomes. In a number of cases Imaginative Mind, instead of asking questions about specific aspects of either light or Mary, expresses exaltation and offers praise of the Virgin. As already noted, sometimes a single word in one of these laudatory lines triggers his discussants to adduce another comparison, which in turn stirs up his imagination - and consequently his emotionseven further.

In a number of speeches Imaginative Mind indicates how he internally processes the verbal analogies presented to him. As early as the prologue, he refers to how the upcoming comparison between Mary and light 'internally touches all his thoughts' ${ }^{157}$ Further on he declares that 'his internal senses start to rejoice..158 Towards the beginning of the play proper, he speaks of his 'internal fundaments' - his heart or soul — being 'delighted this very moment' by the words spoken by his discussants. ${ }^{159}$ Towards the end of the play this mental process reaches a climax, his 'imagination'- this is the only time he refers literally to his internal sense-almost succumbing under the heavy weight of the duty it has to perform: 'All imagination now is melting in me'.160 Nevertheless, according to the following line, cited above, he wants to hear more. Halfway through the eighteenth sequence, Sweet Eloquence expands on the relationship

440 ; 12 ) vss. $441-475^{a}$; 13$)$ vss. $475^{b-502 ; 14) ~ v s s . ~} 503-531 a$; 15$)$ vss. $531 b-568$; 16$)$ vss. $569-$ 604 ; 17 ) vss. $605^{-628}$; 18) vss. 629-664; 19) vss. 665-687. Sequences $1,4,5-8,11-16$ and 18 start with a question or remark by Imaginative Mind. In sequences 2, 3, 9, 17 and 19 the analogy is initiated by Experiential Proof, introducing another physical property of light.

156 Vss. 217, 260, 282, 294, 445, 504, 632, 633 .

157 Vs. 88: 'Ghy beroert inwendich al myn ghedochte'.

158 Vs. 146: 'Myn zinnen inwendich beghunnen te verhueghenne'.

159 Vss. 259-260: 'Myn inwendighe gronden alsnu ten stonden / verblyden duer tvermonden dyns woorts belyden'.

160 Vs. 503: 'Alle ymaginacie alsnu in my smelt'. 
between light and air by comparing it to that between heat and fire and scent and herbs. They belong together and yet are not absorbed into each other. He says to Imaginative Mind: 'In order better to instruct your mind, let this analogy stir your heart.' 161

\section{Light Metaphysics}

As indicated, Everaert's ambition is to compare Mary first and foremost to the primordial light of creation, thus principally defining her as Co-Redemptrix, as Mediatrix between mankind and the Trinity. In doing this, he drew, as far as we can tell, on no source directly relating Mary to primordial light. Everaert derived his information - again, directly or indirectly — from works on either the comparans light or the comparandam Mary, from treatises on light metaphysics and optical theory on the one hand, and devotional texts-sermons, prayers, liturgical songs, etcetera - on the other. Of course, the Bible provided terms and metaphors for the description of both. Authorities in the first category linked light, especially the light created on the first and fourth day, to the Trinity and the hierarchies of angels, but not to Mary. Those in the second category linked Mary to light, its various sources and effects, but not to the light of creation, at least not to the primordial light of Genesis 1:3.

Some of Everaert's sources can be identified with reasonable precision, since in many places he quotes, paraphrases and explicitly refers to a number of authorities in both categories mentioned above. ${ }^{162}$ However, except for one instance, he never mentions a title. To the realm of the physics and metaphysics of light belong Aristotle (called the 'philosopher'-'phylosophe'), Seneca (called the 'wise man'- 'wyse man'), Pseudo-Dionysius and Peter Lombard. To that of Mariology belong Hieronymus, Fulbert of Chartres, Anselm of Canterbury and Bernard of Clairvaux, the latter cited no fewer than six times. ${ }^{163}$

161 Vss. 645-646: 'Updat ghy in tverstant te bet gheleert wort, / laet dese ghelyckenesse hu int herte woelen'.

162 Hüsken, De Spelen I, 37-39. Everaert quotes and / or refers to: Genesis 1:3 (vss. 152-157); Proverbs 8:23 (vss. 167-169); Canticles 4:7 (vss. 240, 249-250); Psalms 95:6 (vss. 280-281); Luke 1:27 (vs. 305); Jeremiah 33:6 (vss. 375-376); Wisdom 7:25-26 (vs. 438); Genesis 1:4 (vss. 465-467); Wisdom 7:10 (vs. 531); Luke 1:41 (vss. 559-560); and Genesis 6:7 (vs. 621).

163 Aristotle: vs. 401 (note: according to the editor 'phylosophe' here refers to Solomon); Seneca: vs. 438 (note: according to the editor 'wise man' refers to Solomon); PseudoDionysius: vs. 482 (possibly also vs. 288 , where he may be the authority referred to by 'philosophe'); vs. 173; Hieronymus: vs. 549; Fulbert of Chartres: vs. 343; Anselm of Canterbury: vs. 695 ; and Bernard of Clairvaux: vss. 179, 281, 495, 499, 593, 685. 
Augustine is cited twice with reference to the first and once with reference to the second area of expertise. ${ }^{164}$ Everaert quotes from (or refers to) Scripture as well. In all likelihood he translated and paraphrased passages from the Vulgate. ${ }^{165}$

The analogy between Mary and light corresponds to a number of ideas about the natural qualities of the latter. The most fundamental concept was that light performed a connecting and communicating function within the hierarchy of being. ${ }^{166}$ It had all started in the beginning, when God said 'Let there be light' (Genesis 1:3) and 'Let there be lights in the firmament of the heavens' (Genesis 1:14). The relation between these two moments is the first aspect of light the play deals with, in the prologue, even before the actual comparison has commenced. In fact, it leads to the first two analogies between Mary and light. Once Sweet Eloquence has established that 'perfect clarity' is the matter to be addressed, Imaginative Mind phrases his first two questions concerning its properties and characteristics, the second repeating the first: 'Was there light or clarity before the time and moment / the sun was made or created?' and 'was of this light [...] the sun made?'.167 Imaginative Mind's discussants answer that God — the 'divine wisdom' ('goddelicke wysheyt')—created light on the first day, a light, however, 'without rays and radiance' ('zonder scynsels of raysele'), from which He created the sun on the fourth. ${ }^{168}$ Mary is identified with the former, Christ with the latter. ${ }^{169}$ Mary's identification with divine knowledge is strengthened by a paraphrase - a conflation in fact, very freely adapted —of Proverbs 8:26-27: 'Before the earth was created or heaven's throne, / I was received in Gods eternal wisdom. ${ }^{\prime}{ }^{170}$ Compared to the Latin original, the words 'Gods eternal wisdom' ('deeuweghe wysheyt Gods') are clearly added.

It is in the context of the creation of light that Everaert refers to Peter Lombard, 'the Master of the Sentences' ('de Meester der Sentencien') or Sententiae. ${ }^{171}$ They contained insights from contemporary science, mathematics

\footnotetext{
164 Augustine: vss. 433b, 471, 641.

165 Hüsken, De Spelen I, 35-37.

166 Hedwig, Sphaera Lucis 13, 29, 36-37.

167 Vss. 150-151: 'wasser licht of claerheyt, eer tyt of stonde / dat de zunne ghemaect was of ghescepen?'; vss. 171-172a: 'was van dese claerheyt [...] de zunne ghemaect?'.

168 Vss. $152,162$.

169 Vss. 166-169; vss. 176-179.

170 Vss. 168-169: 'Eer deerde ghemaect was of shemels troone, / wassic in deeuweghe wysheyt Gods ontfanghen'.

171 Vs. 173. Lombard Peter, The Sentences, Book 2: On Creation, trans. G. Silano (Toronto: 2008).
} 
and logic, ${ }^{172}$ attesting to the position of natural philosophy as a handmaiden to theology. ${ }^{173}$ Lombard addresses the relation between the two forms of light mentioned in Genesis 1 and raises the question why God found it necessary to create light twice. ${ }^{174}$ Light was created on the first day, so that all other things that were to be created could be seen. ${ }^{175}$ Whilst during the first three days the four elements - earth, water, air and fire-were differentiated and ordered in their places, on the next three days they were adorned, beginning with the filling of the firmament with sun, moon and stars. ${ }^{176}$ The latter were created to illuminate the lower part of creation, 'so [it would] not be dark to its inhabitants.' ${ }^{177}$ The light of the first day was associated with human intellect, whereas the light of sun, moon and stars was linked to sensory perception. ${ }^{178}$

Another of Everaert's sources may have been Bartholomew the Englishman's De proprietatibus rerum (On the Property of Things). Bartholomew is not explicitly referred to, but Wim Hüsken, the play's editor, points out a similarity between two lines by Sweet Eloquence and the eighth book of his work about the cosmos. ${ }^{179}$ Like Lombard's Sentences, De proprietatibus rerum was used as a guide to Scripture, but primarily from the angle of natural philosophy. ${ }^{180}$ Like the former it was also widely disseminated in manuscript and print. ${ }^{181}$ Besides making the distinction between 'lux' as the substance of light and 'lumen' as the radiation emerging from it, thus providing a parallel for the distinction made by Everaert between 'licht' ('light') and 'claerheyt' ('clarity'), ${ }^{182}$ Bartholomew

172 Grant, The Nature of Natural Philosophy 37-39, 160, 228-229, 239-240.

173 Ocker, "Scholastic Interpretation of the Bible" 257; and Grant, The Nature of Natural Philosophy 226.

174 Grant, Planets, Stars, and Orbs 390. Also see Lombard, The Sentences 56 (XIII.5 (68).3-4).

175 Lombard, The Sentences 54 (XIII.1 (64)).

176 Ibid. 62 (xv.9 (79).2).

177 Ibid. 62 (XIV.10 (80)).

178 Hedwig, Sphaera Lucis 57 .

179 Vss. 6oo-6o1.

180 Bogaart S., Geleerde kennis in de volkstaal. Van den proprieteyten der dinghen (Haarlem 1485) in perspectief (Hilversum: 2004) 36.

181 Ibid. 37-38; and Meyer H., Die Enzyklopädie des Bartholomäus Anglicus. Untersuchungen zur Überlieferungsgeschichte und Rezeptionsgeschichte von De proprietatibus rerum (Munich: 2000) 397-410.

182 Engelsman Bartholomeus, Van de werelt ende van de materialike lichamen des hemels. Het achtste boekvan Bartholomeus Anglicus' De proprietatibus rerum in een Middelnederlandse vertaling. Uitgegeven naar de drukvan Jacob Bellaert Haarlem 24 dec. 1985, ed. I.M. Gondrie, 2 vols. (Utrecht: 1981) 154 (VIII.29), 158 (VIII, 30); and Bogaart, Geleerde kennis in de volkstaal 11 . Also see the commentary by I.M. Gondrie, the editor of the Middle Dutch translation: Engelsman, Van de werelt 58-59. 
mentions various characteristics of light referred to by Everaert as well, such as light being a spiritual substance of God and the angels, the fact that it makes things grow, and that it remains constant in all circumstances. ${ }^{183}$

The blending of natural philosophy and theology, leading to a metaphysics of light, culminated in Robert Grosseteste's De luce (On light). Everaert does not refer to Grosseteste, but the latter's work is indispensable for a proper understanding of late medieval optical theory. ${ }^{184}$ Its second part deals with the story of creation in terms of light. ${ }^{185}$ Grosseteste defines it as the first corporeal form which, by touching matter, brought about the nine celestial spheres and the four spheres of fire, air, water and earth underneath them. ${ }^{186}$ In fact, he considered the form — species — of all bodies to be light, "but in the higher bodies it is more spiritual and simple, whereas in the lower bodies it is more corporeal and multiplied.' ${ }^{187}$ Everaert's remark in the seventh sequence, that light is fast and omnipresent, only 'blocked / by high edifices such as churches, walls, / through the closing of windows, doors', 188 corresponds with Grosseteste's view that 'a point of light will produce instantaneously a sphere of light of any size whatsoever, unless some opaque object stands in the way'. ${ }^{189}$ Since, according to Thomas Aquinas, God is essentially light (a view we encountered already in Augustine). His relationship with us is the same as that between light and men. ${ }^{190}$

Grosseteste was very familiar with Pseudo-Dionysius, whose work was as intensively studied and commented upon as Lombard's Sentences. ${ }^{191}$ Everaert cites Dionysius at least once, probably from De divinis nominibus (On the Divine Names). ${ }^{192} \mathrm{He}$ also seems to have been familiar with the latter's ideas on the order of angels, as described in De caelesti hierarchia (On the Heavenly Hierarchy). ${ }^{193}$ Dionysius repeatedly draws analogies between natural and

\footnotetext{
183 Ibid. 134 (VIII.17), 153-154 (VIII.29); and Bogaart, Geleerde kennis in de volkstaal 35.

184 Biernoff, Sight and Embodiment 67-68.

185 Grosseteste Richard, On Light (De Luce), ed. C.C. Riedl (Milwaukee, wi: 1978 [1942]) 6.

186 Ibid. 11, 13; Hedwig, Sphaera Lucis 19, 157; and Gilson, Medieval Optics 214.

187 Grosseteste, On Light 15.

188 Vss. 326-327: 'beweert / by hooghe edeficien als kercken, mueren, / by tbutensluten van veynsteren, dueren'.

189 Grosseteste, On Light 10; Grosseteste, On the Six Days of Creation 97; and Grant, Planets, Stars, and Orbs 42.

190 Gilson, Medieval Optics 231-232.

191 Minnis, "Medieval Imagination and Memory" 257.

192 Vss. $482-483$.

193 Vs. 288. Also see vs. 229.
} 
divine light. ${ }^{194}$ Referring to the apocryphal gospel of James (1:17), he argued that natural light, like the Trinity, retained its unity, despite distributing itself to all things, which corresponds with another view from the seventh sequence. ${ }^{195}$ The idea put forward in the eleventh sequence, that fire consumes objects, clearing away all impurities, without itself becoming corrupted, can be found in another important source on medieval light metaphysics, the thirteenthcentury Liber de intelligentiis. ${ }^{196}$ Because of light's ability to spread its rays instantaneously, Thomas Aquinas called it an 'instrumentum caeli', which through its radiation enabled both generation and decline of life. This generative potential of light is described by Everaert in the sixteenth sequence. ${ }^{197}$ When Imaginative Mind calls Mary a 'glittering ruby' ('blynckende robyne'), ${ }^{198}$ thus initiating the fifteenth sequence, Experiential Proof starts expanding on the reflecting qualities of the clear (cleaned and polished) surfaces of stones, a topic which was also addressed in contemporary optics. 199

The nineteenth and last analogy is by far the most complicated of all. Although one is tempted in this analogy as well as in the previous one to translate 'lucht' as 'light', it probably means 'air'-its predominant meaning in Middle Dutch — and more specifically 'aerial layer', 'sphere' or 'heaven'. The nineteenth sequence starts with the following speech by Experiential Proof:

The air, as one may observe from experience, of fire forms the highest firmament. And the light of this air is known to be the right means that provides all knowledge, because the knowledge of it gives knowledge to all that lives.

By which knowledge, as a means, the secrets of the heavens are explored. It also accomplishes all activities of the human mind. ${ }^{200}$

\footnotetext{
194 Gilson, Medieval Optics 222.

195 Vss. 319-330; Gilson, Medieval Optics 226.

196 Vss. 420-424; Hedwig, Sphaera Lucis 16o.

197 Vss. 573-583; Hedwig, Sphaera Lucis 202-203.

198 Vs. 532.

199 Vss. 533-540; Gilson, Medieval Optics 230.

200 Vss. 665-672: 'De lucht, zo men zien mach by exsperiencie, / van den vieren es tupperste firmament. Ende de claerheyt van der lucht die es bekent / de rechte middel die alle kennessen gheift, / want huer kennesse gheift kennesse al dat leift. / By wiens kennesse, als middel, wort besocht / de secreten der hemelen. Ooc worden vulbrocht alle ghewercken in smeinschens verstant'. My interpretation and translation differs from that by Steenbrugge, who, following the editor's annotation, translates 'lucht' with 'light'. Steenbrugge C., "Physical Sight and Spiritual Light in Three Sixteenth-Century Plays
} 
The aerial sphere of fire brings forth the light that inspired human intellect, which in turn is employed to discover the secrets of heaven. Light helps the human mind to function in general. Remarkable is the frequency of the word 'kennesse(n)' ('knowledge')—four times in three lines—-thus stressing the link among light, intellection and Mary. ${ }^{201}$ In fact, we find the word scattered throughout the play, just as the word 'verstant', which may refer either to the instrument ('mind', 'intelligence') or the result ('understanding') of intellection. ${ }^{202}$

In the speech that follows, Sweet Eloquence makes the link with Mary, calling her the 'middel' ('means of communication' or 'medium') between man and the Trinity. Just as the light of the human intellect enables man to discover the secrets of the stars, so too Mary enables man to understand the secrets of the Trinity. He extends the analogy by calling Christ 'the highest sphere' ('dupperste lucht'). ${ }^{203}$ And he concludes the analogy as follows: 'Just as the air is filled with light, / so too you [Mary] have received the highest, God's son, / in your precious blessed body'204 In other words: by bringing forth Christ, she leads us to knowledge about the Trinity. In fact, Everaert turns the analogy around: Christ now is the light and Mary the aerial sphere that produces him.

When Everaert speaks of 'the air [...] of fire' that is 'the highest firmament', identifying it with Christ, calling him 'the highest air', he may simply mean the sky above the earth, as it is described in Genesis 1:7. Grosseteste in his Hexaëmeron (On the Six Days of Creation) wrote that 'Christ and the ranks of heaven [...] are like the firmament'. ${ }^{205}$ But Everaert might as well be referring to one of the spheres or orbs which according to medieval cosmology surrounded the earth, one inside the other, concentrically. The first of these spheres was formed by the elements of water, air and fire. ${ }^{206}$ Then came the

of the Low Countries", Marginalia 3 (2006), electronic article, www.marginalia.co.uk/ journal/o6illumination/steenbrugge.php/, accessed August 21, 2013. Although 'lucht' could mean 'light' in medieval West-Flemish, it usually refers to 'air'. Moreover, why would Everaert use 'lucht' to mean 'light', where in four instances he uses the word 'licht' (vss. $150,154,512,701)$ ?

201 Vss. 668-670; Steenbrugge, "Physical Sight and Spiritual Light".

202 Vss. 19, 219, 256, 459, 546, 668-670, 675 ('kennesse(n)'); vss. 11, 40, 74, 84, 214, 219, 397, 566, 645,672 ('verstant').

203 Vs. 680.

204 Vss. 682-684: 'Want zo by der claerheyt de lucht es bevanghen, / so hebt ghy den uppersten Gods Zuene ontfanghen / in hu precious lichaerme ghebenendyt'.

205 Grosseteste, On the Six Days of Creation 196.

206 Grant, The Nature of Natural Philosophy 141. 
celestial spheres, starting with the seven planetary spheres. ${ }^{207}$ The sphere meant by Everaert must be one associated with fire and light, though probably not the one formed by the element fire, that one being too close to earth. Could it be the eighth sphere then, that of the fixed stars, where Dante in his Divina Comedia (Divine Comedy) witnessed 'the luminous triumphs of Christ and Mary'?208 Or does he mean the ninth, where Dante saw God and the angelic hierarchies 'as a point of light surrounded by the nine fiery circles'?209 He might even hint at the eleventh or outermost sphere, the empyrean heaven, which was described as 'a place of dazzling luminosity'.210 Still another option is that Everaert thought of aether, the fifth element or quintessence, which was supposed to carry light from the highest parts of the cosmos to the lowest. It also became identified with the cosmos at large, with Christ even, and was known to form a separate sphere, too. ${ }^{211}$ Bartholomew the Englishman defines it as follows: 'the aetherial sky according to some masters is called the highest firmament of the air, which is directly connected to the sphere of fire.'.212

\section{Mariology}

Of all doctors of the church, none was as strongly associated with Mary as Bernard of Clairvaux, an association based on the popularity of the iconographical themes of the lactatio and the amplexus, as well as on a number of eloquently phrased texts and passages. Despite its flowery, exalted formulation, Bernard's views fit into a traditional theology that is biblical and sober. ${ }^{213}$ The Cistercians' link with Mary was manifested in their abbots' custom of preaching on Marian feast days: the Annunciation, Purification, Nativity and Assumption. ${ }^{214}$ Bernard himself was no exception to this rule. One of the six

\footnotetext{
207 Ibid. 143.

208 Gilson, Medieval Optics 217.

209 Ibid.

210 Grant, The Nature of Natural Philosophy 144. Also see Lombard, The Sentences 11 (II.4 (10).5).

211 Böhme - Böhme, Feuer, Wasser, Erde, Luft 143-145, 147.

212 Engelsman, Van der werelt 100 (VIII.2): 'Celum etherum hiet na sommigen meysters dat alre overste onderscot der luchten, twelc sonder middel versament is mitten spere des viers'.

213 Bell, Bernardus dixit 296; and Reynolds, Gateway to Heaven 215.

214 Casey M., "Reading Saint Bernard: The Man, the Medium, the Message", in McGuire B.P. (ed.), A Companion to Bernard of Clairvaux, Brill's Companions to the Christian Tradition 25 (Leiden - Boston: 2001) 62-107, esp. 86.
} 
references made to him in the play may concern a passage on Mary's humility taken from the Homiliae super evangelio Missus est angelus Gabriel, though Everaert does not refer to this work explicitly. ${ }^{215}$ The Homiliae do not consist of verbatim versions of Bernard's sermons, but are literary adaptations in the exuberant style that became Bernard's hallmark. ${ }^{216}$ They became widely disseminated in both manuscript and print.

It was very common to compare the relationship between Mary and Christ in terms of the sun, the moon and the stars created on the fourth day. Alain de Lille, for example, compared Mary to the moon and to a star because she gave birth to Christ, the 'Sun of Justice.'217 The liturgy—prayers and chants at Mass and the Divine Office - provided a lot of metaphors for Mary, light being one of them. From the tenth century onwards a number of Marian tropes-embellishments of the sung responses of the Mass, such as the Kyrie, the Gloria, the Sanctus and the Agnus Dei-became extremely popular. The one containing the most light metaphors was the Ave Maris Stella (Hail Star of the Sea): 'Hail most bright star of the sea, a light for the nations, [...] Queen of heaven, outstanding as the sun, beautiful as the flesh of the moon [...].218 It seemed obvious that Mary (and/or Christ) should be compared to the moon and the sun, since, given the quantity of light comprised by them, they were thought to affect lower bodies more than any of the other planets. ${ }^{219}$ Conrad of Saxony, inspired by Canticles 6:10-a treasure house of Marian metaphors-compared Mary to the dawn, the moon and the sun, and praised her 'luminous virginity', her 'luminous fruitfulness' and her 'luminous uniqueness'.220 Jean Gerson called her Illuminatrix, who bestows light because of her natural generosity. He even explained her name etymologically as 'star of the sea.' ${ }^{221}$ Besides the sun, the moon and the stars, the rainbow also provided a powerful metaphor for Mary, especially for her role as Mediatrix who bridges the distance

\footnotetext{
215 Vss. 178-179.

216 Casey, "Reading Saint Bernard" 87.

217 Reynolds, Gateway to Heaven 146.

218 'Ave praeclara maris stella, / in lucem gentium [...] regina coeli, / praeelecta ut sol, / pulchra lunaris ut fulgor [...]'. Gambero L., Mary in the Middle Ages: The Blessed Virgin Mary in the Thought of Medieval Latin Theologians, trans. Th. Buffer (San Francisco: 2005) 69; Reynolds, Gateway to Heaven 200-201.

219 Gilson, Medieval Optics 187, and n. 44; and also see 208-209, 218, 224, for examples of light imagery in Dante's description of creation, the Trinity, and its relation to man in the Divina Comedia.

220 Gambero, Mary in the Middle Ages 218.

221 Ibid. 283-284.
}

\section{For use by the Author only | (c) 2015 Koninklijke Brill NV}


between God and man. ${ }^{222}$ The close analogy to the Trinity which dominates the nineteenth sequence of the comparison was very eloquently described and explained by Raymond Lull. All three persons of the Trinity, he said, were present at the Annunciation: God the Father when the angel greeted her, the Holy Spirit when he breathed himself into her, and Christ when he took flesh from her. ${ }^{223}$

The Franciscans (and from the middle of the thirteenth century onwards the Dominicans, too) also stimulated Marian devotion. Among them were Bonaventure, Robert Grosseteste and John Duns Scotus, the latter becoming a champion of the doctrine of Mary's immaculate conception. ${ }^{224}$ Bonaventure, like Bernard, stressed her central role in the salvation process, as Co-Redemptrix interceding on man's behalf. ${ }^{225} \mathrm{He}$ distinguished between three degrees of honor due to God, the saints and Mary, using the terms latria (adoration), dulia (veneration) and hyperdulia (deep veneration). The first was to be offered to God and Christ, the second to the saints, the third to Mary. She deserved this extra veneration because of her unique position. ${ }^{226}$ At the moment of conception, her soul was infused with sympathy and clarity, exempting her from original $\sin .^{227}$

Thus, we see how the cosmological insights discussed in the previous paragraph entered Marian metaphorics and became integrated in the liturgy and theology of the Blessed Virgin, stimulating fervent devotion toward her. This becomes particularly apparent in Everaert's play at the moments of heightened attention accompanying disclosure of the two tableaux vivants. The first, which appears at the end of the prologue and portrays Queen Esther kneeling before Ahasuerus, is announced by Grounded Scripture, who paraphrases the first line of the responsory Felix namque: 'All worthy, / blessed Mary, art thou of praise / since from thy light has risen / the sun, Christ, who has taken away / Satan's power by His holy might'.228 Just a few lines before he has concluded the comparison of Mary to the primordial light in Genesis 1:3 and that

222 Ibid. 201, 279.

223 Ibid. 260.

224 Reynolds, Gateway to Heaven 228, 231; and Rubin M., Mother of God: A History of the Virgin Mary (London: 2010) 197-198.

225 Reynolds, Gateway to Heaven 215, 238; and Gambero, Mary in the Middle Ages 149, 152, 228.

226 Reynolds, Gateway to Heaven 237-238; Gambero, Mary in the Middle Ages 213, 231.

227 Reynolds, Gateway to Heaven 361.

228 Vss. 184-188: 'Alle weerdichede, / ghebenendyde Maria, zyt ghy om loven / want uut hu claerheyt es gheresen te boven / de zunne, Christus, die svyants macht / benomen heift by Zyn heleghe cracht'. In Latin de first line reads: 'Felix namque es, sacra Virgo Maria, et omni laude dignissima, quia ex te ortus est sol justitiae, Christus Deus noster' ('For thou 
of Christ to the sun in Genesis 1:4, calling Him 'the sun of justice' ('de zunne der rechtvaerdichede'), ${ }^{229}$ exactly the same epithet as can be found in the responsory. Grounded Scripture introduces his paraphrase of the first line as follows: 'The holy church sings:' ('De heleghe kerck synght:'), thus suggesting that during the presentation of the living image, following his speech, the Felix namque was indeed sung. Through the performance of this responsory, Everaert intended to underline not just Mary's intercessional role per se, but also the basis for it in the creation of light as described in Genesis 1. Its presence also reveals his familiarity with the liturgy of the major Marian feasts and with the liturgy of the Hours, particularly the so-called Little Office of the Virgin. Most of its content was taken from the liturgy of these feasts, particularly that of the Assumption (15 August). ${ }^{230}$ Moreover, the Little Office establishes her in a number of roles, but primarily in that of the Mediatrix between heaven and earth, interceding on man's behalf before the Trinity. ${ }^{231}$

Felix namque was sung on both the Assumption and the Nativity of the Virgin (8 September), and was part of the Little Office as well. ${ }^{232} \mathrm{~A}$ further indication of how much the liturgy of these feasts must have been present in Everaert's mind while composing the play is Proverbs 8:22-35, from which Grounded Scripture paraphrases two verses, some twenty lines before quoting from Felix namque. The same passage formed one of the readings for that same feast of the Nativity, the liturgy of which contained multiple references to her motherhood of Christ.

Marian antiphons were sung almost daily, ${ }^{233}$ especially in churches and chapels devoted to her, where chantries were established in her honor. The collegiate church of Our Lady in Bruges possessed a very rich tradition of Marian chant. Every Saturday its clergy sang a Lady-mass. ${ }^{234}$ Mary of Burgundy, whose remains were buried there, had established a chantry, stipulating, among other things, the daily singing of a Marian mass after matins in discant, with two

art happy, O holy Virgin Mary, and art worthy of all praise, for out of thee arose the Sun of justice, Christ our God').

229 Vs. 177.

230 Baltzer R.A., "The Little Office of the Virgin and Mary's Role in Paris", in Fassler M.E. Baltzer R.A. (eds.), The Divine Office in the Latin Middle Ages: Methodology and Source Studies, Regional Developments, Hagiography (Oxford: 2000) 463-484, esp. 466.

231 Ibid. 470-471.

232 Ibid. 468, 475 .

233 Haggh B., "Nonconformity in the Use of Cambrai Cathedral: Guillaume Du Fay's Foundations", in Fassler - Baltzer (eds.), The Divine Office in the Latin Middle Ages 372-397, esp. 384; and Brown, Civic Ceremony 111-112.

234 Strohm, Music in Late Medieval Bruges (Oxford: 1990) 43. 
voices or parts sung in consonant intervals. ${ }^{235}$ Everaert must have heard the confraternitas chori of the church sing at many occasions. After all, the chamber of The Three Saints, of which he was a member, had its chapel there. ${ }^{236}$ The clergy of the parish church of St. Saviour likewise had a confraternitas chori, this one dedicated to Mary's Assumption. ${ }^{237}$ When the annual procession of the Holy Blood passed the church of Our Lady, Felix namque was sung, 'a tune probably everyone in Bruges knew, so often does it occur in the liturgies of the various churches'.238 The Annunciation was one of the topics that was staged as a tableau vivant in the procession. The actors sang Marian chants written on the banderols they were holding. ${ }^{239}$

\section{Ultimate Vision, Ultimate Knowledge}

At the end of nineteenth sequence Grounded Scripture, Experiential Proof and Sweet Eloquence begin to prepare Imaginative Mind for his ultimate experience of the analogy between Mary and light: the tableau vivant in which the comparison culminates. According to a stage direction, the tableau consists of the Blessed Virgin standing-perhaps even hovering-between heaven and earth, between the Trinity enthroned above and mankind situated below. Three rays of light, coming from the mouths of the three divine persons- - banderols perhaps, carrying Marian texts, such as those used in the procession of the Holy Blood - shine down on Mary's head, while a fourth ray, coming from her own mouth, descends earthward. By way of conclusion-'mind the conclusion' ('verstaetet slot'), ${ }^{240}$ says Sweet Eloquence-all three discussants stress her mediating position verbally, quoting Bernard of Clairvaux and Anselm of Canterbury. Possibly, the living image is disclosed already at the moment when Grounded Scripture quotes an unidentified passage from the former's work, containing the words: 'behold the light, Mary' ('ansiet de claerheyt, Maria'). ${ }^{241}$ But it is definitely revealed when Grounded Scripture emphatically exclaims: 'Open your eyes, fall to your knees' ('Opent hu ooghen, valt up hu knyen'). ${ }^{242}$

\footnotetext{
235 Ibid. 49.

236 Ibid. 47.

237 Ibid. 51.

238 Ibid. 5-6.

239 Ibid. 6-7.

240 Vs. 692.

241 Vs. 687.

242 Vs. 697.
} 
All kneel and join in the declamation of a sophisticated panegyric on Mary in retrograde verse, in which the words 'darkness', 'light' and 'clarity' abound. The first or last line of each stanza is a variant of the opening words of the Annunciation: 'Hail Mary, glittering light' ('Ghegroet weist, Maria, clearheyt blynckende') (Luke 1:28).243

The iconography of the living image shows the influence of various categories of Marian iconography. As far as her position between heaven and earth is concerned, representations come to mind of her celestial appearances, such as the Assumption, or as Mary in the Sun, which was inspired by the woman from Revelation 12:1-6: 'And a great portent appeared in heaven: a woman clothed with the sun, with the moon under her feet, and on her head a crown of twelve stars'. Mary in the Sun often appeared as the subject of woodcuts in popular prayer books, such as Onser lieuer vrouwen croon (Our Blessed Lady's Crown) [Fig. 11.1]. There are derivations from Annunciation imagery as well, ${ }^{244}$ especially the three rays coming from the Trinity that shine down on Mary's head. The paraphrase of the first words of the Ave Maria (Hail Mary), in the laudatory poem accompanying the image, hints at this as well. The tableau shares elements with one kind of Annunciation iconography in particular: the socalled conceptio per aurem ('conception through the ear'), whereby the trajectory of Christ's decent along rays of light leads not to Mary's womb, but to her ear. It was probably triggered by the notion of Christ being the Logos ('Word'), according to John 1:1, and possibly also by Ecclesiasticus 24:3. ${ }^{245}$ In fact, the opening verses of chapter 24 perfectly capture the cosmological dimensions of Mary's relation to the Trinity, as exemplified in the second analogy of the prologue and in the nineteenth analogy of the play:

Wisdom shall praise herself, and shall glory in the midst of her people. In the congregation of the most High shall she open her mouth, and triumph before his power.

I came out of the mouth of the most High, and covered the earth as a cloud.

I dwelt in high places, and my throne is in a cloudy pillar.

I alone compassed the circuit of heaven, and walked in the bottom of the deep.

\footnotetext{
243 Vs. 716.

244 See the commentary by the play's editor on the stage direction above vs. 700 .

245 Mak J.J., Middeleeuwse kerstvoorstellingen (Utrecht - Brussels: 1948) 33 .
}

\section{For use by the Author only | (c) 2015 Koninklijke Brill NV}




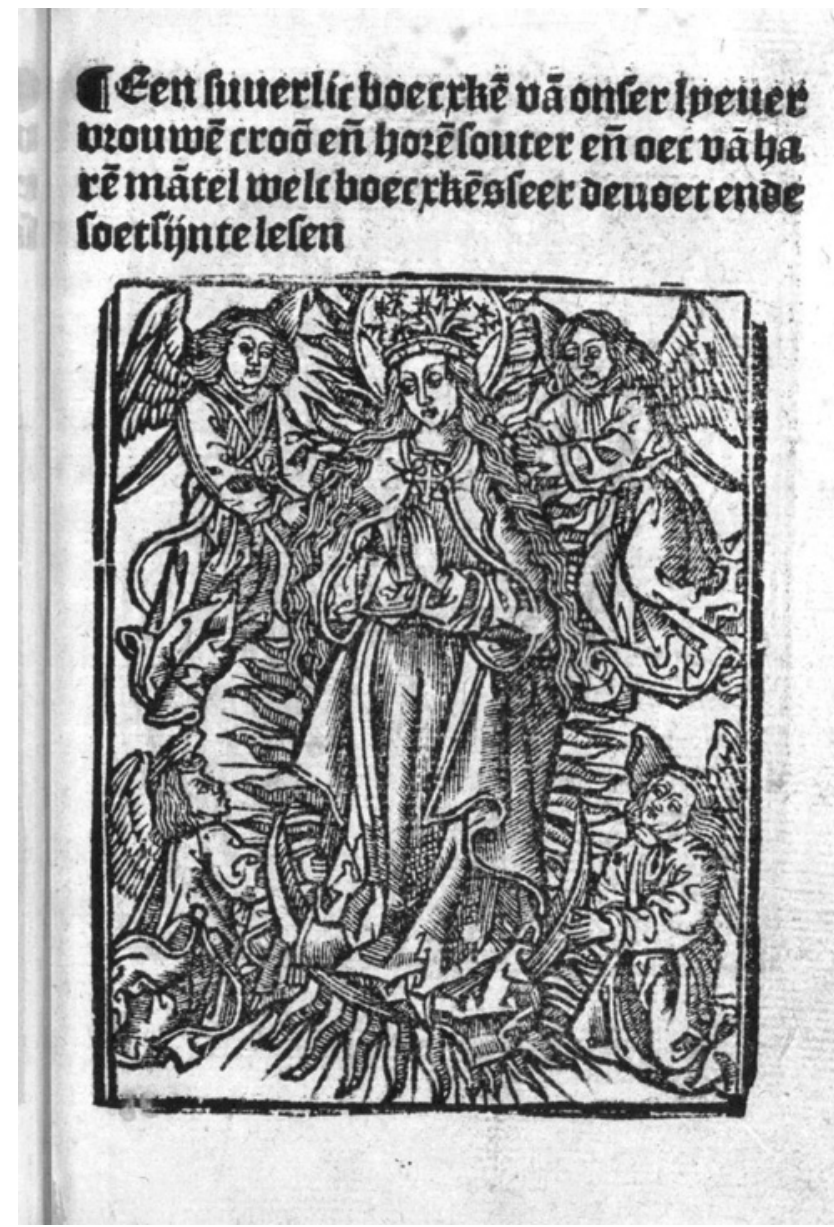

FIGURE 11.1 "Mary in the Sun", woodcut illustration to Een suuerlic boecxken van onser liever Vrouwen croon (Leiden:Jan Seversz., after 1513), The Hague, Royal Library: 228 G $1, f$. Avv.

IMAGE (C) PROQUEST LLC.

Although the 'I' in these verses is normally identified with Christ, the text might as well apply to Mary, given her position between heaven and earth and her association with divine wisdom and knowledge in the aforementioned analogues. ${ }^{246}$ If the rays were banderols containing texts, either in Latin or Middle Dutch, those coming from the Trinity possibly had passages from the Ave Maria painted on them, whereas the one coming from Mary might have

246 Vss. 152, 169.

For use by the Author only | (C) 2015 Koninklijke Brill NV 
contained her final response to that message: 'Behold, I am the handmaid of the Lord; let it be to me according to your word' (Luke 1:38). But equally appropriate were Proverbs 8:26-27, paraphrased by Grounded Scripture in the second analogy of the prologue, which explicitly links Mary to the divine wisdom that brought forth, and was shown in, creation. She was not just the Sedes Sapientiae ('Throne of Wisdom'), but the embodiment of wisdom itself. ${ }^{247}$

This tableau vivant is an example of what Sixten Ringbom calls an 'imaginative devotion'. He argues that miniatures of Mary in the Sun (among others) functioned as apparitions to the owners of the medieval books of hours in which they featured. These were no mystics or visionaries to whom Mary had really appeared. They merely envisaged such scenes as part of their devotional life, imagining them-and having them painted in their prayer books-as if they were real visions. ${ }^{248}$ In late medieval devotional art we come accross scenes comparable to that with Imaginative Mind genuflecting before a tableau vivant of Mary and the Trinity, reciting words of praise, scenes in which lay donors are likewise represented looking up at Mary in the Sun, suggesting that they possess spiritual vision.

Although Imaginative Mind is explicitly called upon to open his eyes, there is no indication in the text that he is suddenly been cured of his blindness. On the contrary, I believe that at this point he too was seen to exercise spiritual vision and inner sight. The image in question is especially suited to stimulate such vision. Styled after Revelation 12, its meditative purpose becomes even more apparent. Augustine characterized this Bible book as a prime example of spiritual vision, the intermediate level in his tripartite theory of vision. ${ }^{249}$ Given the intellectual overtones of the play — material light and sight leading to human knowledge, spiritual light and sight leading to divine knowledge, with Mary as the means of going from one level to the next-one might wonder whether Imaginative Mind, in this final moment, achieves a state of intellectual vision in the Augustinian sense, moving from scientia to sapientia in its purest form, the state of knowledge identified with divinity itself. Grosseteste spoke of the mind ascending 'to the contemplation of the Trinity', bringing back 'a light of fear from the power of the Father, a light of knowledge from the wisdom of the Son, and a light of love from the kindness of the Holy Spirit'.250

\footnotetext{
247 Rothstein, Sight and Spirituality 74-75.

248 Ringbom, “Devotional Images and Imaginative Devotions” 166.

249 Augustine, De Genesi ad litteram 12.6 ff.; Newman, "What Did It Mean to Say 'I saw'?" 6-7; and Minnis, "Medieval Imagination and Memory" 246.

250 Schumacher, Divine Illumination 141-142.
} 
Light was thought of as establishing a direct link between God, exemplified in the Trinitarian image. ${ }^{251}$

Everaert identifies Mary with that light. His play testifies to the high level of theological as well as devotional sophistication that the urban middle classes had reached by the early sixteenth century. The fact that it was written for the occasion of a widely attended urban religious festival, in a well-known and broadly practiced theatrical genre, and in competition with like-minded and equally spirited laymen, all trying their best to compare Mary to light, may serve as proof of the established and pervasive character of their religious ambitions, as well as of their literary prowess in expressing and further developing them. As stated, the competition of plays for which Evaeraert wrote his work was linked to the annual Corpus Christi procession held in the town of Nieuwpoort. Like the procession, the contest was a public, communal celebration of lay civic character. Though blind, Imaginative Mind is presented as an example to the audience; he literally comes out of their midst. ${ }^{252}$ What he aims for, they should aim for as well; what he achieves, they can achieve too.

Although this and other comparations - such as the allegorical plays of the rhetoricians in general - follow the structure of the scholastic disputation and employ personifications that act out an argument, ${ }^{253}$ thus putting a rational stamp on the genre, all this reasoning on the basis of both the natural world and Scripture was driven by, and by the end of the plays led to, affective piety on the part of the main character whose striving for knowledge forms the impetus for the stage action. If a statue of the Blessed Virgin was indeed present on or somewhere near the stage during the play, it could have featured as a reminder or perhaps even as the addressee of the plays in which she was compared to the light - light which, in Everaert's contribution, clarified the main character's mind, through both its natural and spiritual meanings and effects, and offered him the opportunity to see Mary not only analogically, through imagination, but also directly, in a vision, casting his inner eye past or through her, at the Trinity, before which she interceded on his behalf.

251 Karnes, Imagination, Meditation, and Cognition 70.

252 In the other comparations, the mankind characters expressly present themselves as representatives of the burgher class. Request to Know (Besouck om Weten) from Saint Peter Compared to the Dove, is a male character dressed 'like a burgher' ('als een poorter'; Hüsken, De Spelen II, 679, above vs. 1), while Joyous Desire (Jonstich Begheerren) from Mary Compared to the Throne of Solomon, is dressed 'like an honest burgher or alderman' ('als een eerlic poortere ofte wethouder'; see Hüsken, De Spelen II, 596, above vs. 1).

253 Simpson, "From Reason to Affective Knowledge" 11. 
Thus, the Mary presented to us by Everaert is not so much 'Mary, local and familiar', but rather 'Mary the sublime' and 'Mary: unlike any other', to quote three chapter titles of Mary Rubin's recent book Mother of God. The Mary we encounter in this play is not the one who 'took on increasingly the features of daily life,'254 not the wonder-worker of the miracle plays, nor the weeping mother underneath the cross of many passion plays. ${ }^{255}$ The shift from Latin to the vernacular and her institutionalized veneration within civic confraternities such as the chambers of rhetoric certainly made her more approachable, but did not necessarily go hand in hand with simplification and vulgarization. Everaert and his fellow rhetoricians in a way belie what Rubin calls 'the poetic impossible' of Mary, the 'impossibility of capturing [her] fullness'.256 They were up to the challenge.

To conclude, I would like to elucidate the meaning of Imaginative Mind by comparing this character to the Dreamer in William Langland's Piers Plowman and, of course, to his near namesake in that poem, Ymaginatif, who acts as one of the Dreamer's advisors. ${ }^{257}$ Like Imaginative Mind, Ymaginatif represents the reasoning power of the imagination, the vis imaginativa. ${ }^{258} \mathrm{He}$ is described as the faculty that produces images, but also as the ability to compare and analyze these images rationally. ${ }^{259}$ Drawing analogies and associations has been called a distinctive trait of his verbal actions. ${ }^{260}$ We can also compare Imaginative Mind to the Dreamer, who is taught by Ymaginatif how to use his imaginative faculty. In comparable ways, Imaginative Mind is instructed by his three discussants to imagine Mary's spiritual significance by comparing her to a natural, sensory phenomenon-light — the natural properties of which are described to him with empirical precision. Let me conclude, then, by paraphrasing Alastair Minnis's description of the Dreamer in Piers Plowman and applying it to Imaginative Mind: in the end his imagination, through the images of the things present to the exterior senses, moves his will to stimulate reason, so that it considers (or beholds) Mary spiritually, as Mediatrix. Like the Dreamer, his imaginative vision is stimulated, and he is brought to intellectual

\footnotetext{
254 Rubin, Mother of God 199.

255 Ibid. 199, 197-256.

256 Ibid. 280.

257 Minnis, "Langland's Ymaginatif" 82.

258 Kaulbach, "The 'Vis Imaginativa' " 26-27; and Kaulbach "The 'Vis Imaginativa secundum Avicennam'” 496.

259 Kaulbach, “The 'Vis Imaginativa'” 28.

26o Hanna III R., "Langland's Ymaginatif: Images and the Limits of Poetry”, in: Dimnick Simpson - Zeeman, Images, Idolatry, and Iconoclasm 81-94, esp. 82, 84-85.
} 
vision in as far as the personifications advising him explain the significance of visible and invisible things, culminating in that particular vision based on Revelation. ${ }^{261}$

\section{Bibliography}

Aquinas St Thomas, The Division and Methods of the Sciences: Questions V and VI of his Commentary on the De Trinitate of Boethius, ed. A. Maurer (Toronto: 1963).

Baltzer R.A., "The Little Office of the Virgin and Mary's Role in Paris", in Fassler M.E. Baltzer R.A. (eds.), The Divine Office in the Latin Middle Ages: Methodology and Source Studies, Regional Developments, Hagiography (Oxford: 2000) 463-484.

Bell T., Bernardus dixit. Bernardus van Clairvaux in Martin Luthers werken (Ph.D. dissertation, University of Amsterdam, 1989).

Biernoff S., Sight and Embodiment in the Middle Ages (New York: 2002).

Böhme G. - Böhme H., Feuer, Wasser, Erde, Luft. Eine Kulturgeschichte der Elementen (Munich: 1996).

Bogaart S., Geleerde kennis in de volkstaal. Van den proprieteyten der dinghen (Haarlem 1485) in perspectief (Hilversum: 2004).

Brann E.T.H., The World of the Imagination: Sum and Substance (Boston Way Lanham, MD: 1991).

Brown A., Civic Ceremony and Religion in Medieval Bruges c. 1300-1520 (Cambridge: 2011).

Carruthers M., "Imaginatif, Memoria, and 'The Need for Critical Theory' in Piers Plowman Studies", The Yearbook of Langland Studies 9 (1995) 103-120.

Cary Ph., Augustine's Invention of the Inner Self: The Legacy of a Christian Platonist (Oxford: 2000).

Casey M., "Reading Saint Bernard: The Man, the Medium, the Message", in McGuire B.P. (ed.), A Companion to Bernard of Clairvaux, Brill's Companions to the Christian Tradition 25 (Leiden - Boston: 2001) 62-107.

Dimnick J. - Simpson J. - Zeeman N. (eds.), Images, Idolatry, and Iconoclasm in Late Medieval England (Oxford: 2002).

Drewes J.B., 'Het interpreteren van godsdienstige spelen van zinne', Jaarboek "De Fonteine" 29 (1978-1979) 5-124.

Engelsman, Bartholomeus, Van de werelt ende van de materialike lichamen des hemels. Het achtste boek van Bartholomeus Anglicus' De proprietatibus rerum in een Middelnederlandse vertaling. Uitgegeven naar de druk van Jacob Bellaert Haarlem 24 dec. 1485, ed. I.M. Gondrie, 2 vols. (Utrecht: 1981).

261 Minnis, "Langland's Ymaginatif" 83, 94. 
Falkenburg R., The Land of Unlikeness: Hieronymus Bosch, The Garden of Earthly Delights (Zwolle: 2011).

Fraeters V., "Visio/Vision", in Hollywood - Beckman, Christian Mysticism 178-188.

Gambero L., Mary in the Middle Ages: The Blessed Virgin Mary in the Thought of Medieval Latin Theologians, trans. Th. Buffer (San Francisco: 2005).

Gill M.J., "Augustine's Light", Allegorica 23 (2002) 32-54.

Gilson S.A., Medieval Optics and Theories of Light in the Works of Dante, Studies in Italian Literature 8 (Lewiston et al.: 2000).

Grant E., Planets, Stars, and Orbs: The Medieval Cosmos, 1200-1687 (Cambridge: 1994).

, The Nature of Natural Philosophy in the Late Middle Ages (Washington, DC: 2010).

Grosseteste Richard, On Light (De luce), ed. C.C. Riedl (Milwaukee, wI: 1978 [1942]). , On the Six Days of Creation: A Translation of the Hexaëmeron, ed. C.F.J. Martin (Oxford: 1996).

Haggh B., "Nonconformity in the Use of Cambrai Cathedral: Guillaume Du Fay's Foundations", in Fassler M.E. - Baltzer R.A. (eds.), The Divine Office in the Latin Middle Ages. Methodology and Source Studies, Regional Developments, Hagiography (Oxford: 2000) 372-397.

Hahn C., "Visio Dei. Changes in Medieval Visuality", in: Nelson R.S. (ed.), Visuality before and beyond the Renaissance. Seeing as Others Saw (Cambridge: 2000) 169-196.

Hamburger J.F., "Mysticism and Visuality", in Hollywood - Beckman 2012, Christian Mysticism 277-293.

Hamm B., Religiosität im späten Mittelalter. Spannungspole, Neuaufbrüche, Normierungen, ed. R. Friedrich - W. Simon (Tübingen: 2011).

Hanna III R., "Langland's Ymaginatif: Images and the Limits of Poetry", in: Dimnick Simpson - Zeeman, Images, Idolatry, and Iconoclasm 81-94.

Harbison C., "Visions and Meditations in Early Flemish Painting", Simiolus 15 (1985) $87-118$.

Hatfield G., "The Cognitive Faculties", in Garber D. - Ayers M. (eds.), The Cambridge History of Seventeenth-Century Philosophy (Cambridge: 2003) 951-1002.

Hedwig K., Sphaera Lucis. Studien Zur Intelligibilität des Seienden im Kontext der mittelalterlichen Lichtspekulation, Beiträge zur Geschichte der Philosophie und Theologie des Mittelalters, Neue Folge 18 (Münster: 1980).

Hollywood A. - Beckman P.Z. (eds.), The Cambridge Companion to Christian Mysticism (Cambridge: 2012).

Hüsken W.N.M. (ed.), De Spelen van Cornelis Everaert, 2 vols. (Hilversum: 2005). Jaroszýnski P., Beauty and Being: Thomistic Perspectives (Toronto: 2011).

Karnes M., Imagination, Meditation, and Cognition in the Middle Ages (Chicago London: 2011). 
Kaulbach E.N., "The 'Vis Imaginativa' and the Reasoning of Ymaginatif in the B-Text of 'Piers Plowman', The Journal of English and Germanic Philology 84 (1985) 16-29.

_ , "The 'Vis Imaginativa secundum Avicennam' and the Naturally Prophetic Powers of Ymaginatif in the B-Text of 'Piers Plowman'”, The Journal of English and Germanic Philology 86 (1987) 496-514.

Kay S., The Place of Thought: The Complexity of One in Late Medieval French Didactic Poetry (Philadelphia: 2007).

Lindberg D.C., Theories of Vision from Al-Kindi to Kepler (Chicago - London: 1976).

Lombard Peter, The Sentences, Book 2: On Creation, trans. G. Silano (Toronto: 2008).

Louth A., "Apophatic and Cataphatic Theology", in Hollywood - Beckman, Christian Mysticism 137-146.

MacCormack S., "Augustine on Scripture and the Trinity", in Vessey M. (ed.), Reid S. (assist.), A Companion to Augustine (Chichester: 2012) 398-415.

McGinn B., "Love, Knowledge, and Mystical Union in Western Christianity: Twelfth to Sixteenth Centuries", Church History 56 (1987) 7-24.

- "Visions and Visualizations in the Here and Hereafter", Harvard Theological Review 98 (2005) 227-246.

Mak J.J., Middeleeuwse kerstvoorstellingen (Utrecht - Brussels: 1948).

Matthews G.B., "Knowledge and illumination", in: Stump E. - Kretzmann N. (eds.), The Cambridge Companion to Augustine (Cambridge: 2001) 171-185.

Meyer H., Die Enzyklopädie des Bartholomäus Anglicus. Untersuchungen zur Überlieferungsgeschichte und Rezeptionsgeschichte von De proprietatibus rerum (Munich: 2000).

Milner M., The Senses and the English Reformation (Farnham, Surrey - Burlington, vT: 2011).

Minnis A., "Langland's Ymaginatif and Late-Medieval Theories of Imagination", Comparative Criticism 3 (1981) 71-103.

-, "Medieval Imagination and Memory", in Minnis A. - Johnson I. (eds.), The Cambridge History of Literary Criticism, Vol. 2: The Middle Ages (Cambridge: 2005) 237-274.

Moser N., "Maria verklaard. Everaert als exegeet in Maria ghecompareirt byde claerheyt (1511)", in: Dijk H. van - Ramakers R. et al., Spel en spektakel. Middeleeuws toneel in de Lage Landen, Nederlandse literatuur en cultuur in de middeleeuwen 23 (Amsterdam: 2001) 246-262, 369-377.

- De strijd voor rhetorica. Poëtica en positie van rederijkers in Vlaanderen, Brabant, Zeeland en Holland tussen ca. 1450 en ca. 1620 (Amsterdam: 2001).

Newman B., "What Did It Mean to Say 'I saw'? The Clash between Theory and Practice in Medieval Visionary Culture", Speculum 80 (2005) 1-43.

Ocker Ch., "Scholastic Interpretation of the Bible", in Hauser A.J. - Watson D.F. (eds.) Kaufman S. (ass. ed.), A History of Biblical Interpretation, Vol. 2: The Medieval through the Reformation Periods (Grand Rapids, MI - Cambridge: 2009) 254-279. 
Park K., "Observation in the Margins, 500-1500", in Daston L. - Lunbeck E. (eds.), Histories of Scientific Observation (Chicago - London: 2011) 15-44.

Pasnau R., Theories of Cognition in the Later Middle Ages (Cambridge: 1997).

Pleij H., "De laatmiddeleeuwse rederijkersliteratuur als vroeg-humanistische overtuigingskunst”, Jaarboek “De Fonteine” 34 (1984) 65-96.

Poirel D., "The Spirituality and Theology of Beauty in Hugh of St. Victor", in Matter E.A. - Smith L. (eds.), From Knowledge to Beatitude: St. Victor, Twelfth-Century Scholars, and Beyond. Essays in Honor of Grover A. Zinn, Jr. (Notre Dame, IN: 2013) 247-280.

Pomata G., "Observation Rising: Birth of an Epistemic Genre, 1500-1650", in Daston L. - Lunbeck E. (eds.), Histories of Scientific Observation (Chicago - London: 2011) $45^{-80 .}$

Ramakers B., Spelen en figuren. Toneelkunst en processiecultuur in Oudenaarde tussen middeleeuwen en moderne tijd (Amsterdam: 1996).

— , "Dutch Allegorical Drama: Tradition and Conceptual Approach", in Strietman E. - Happé P. (eds.), Urban Theatre in the Low Countries, 1400-1625, Medieval Texts and Cultures of Northern Europe 12 (Turnhout: 2006) 127-147.

— Book, Beads and Bitterness: Making Sense of Gifts in Two Table Plays by Cornelis Everaert, in Corbellini S. - Hoogvliet M. - Ramakers B. (eds.), Discovering the Riches of the Word: Religious Reading in Medieval and Early Modern Times, Intersections: Studies in Early Modern Culture 38 (Leiden - Boston: 2015) 141-170.

Reynolds B.K., Gateway to Heaven: Marian Doctrine and Devotion, Image and Typology in the Patristic and Medieval Periods, Vol. 1: Doctrine and Devotion (Hyde Park, NY: 2012).

Ringbom S., "Devotional Images and Imaginative Devotions: Notes on the Place of Art in Late Medieval Private Piety", Gazette des Beaux-Arts 73 (1969) 159-170.

Rothstein B.T., Sight and Spirituality in Early Netherlandish Painting (Cambridge: 2006). Rubin M., Mother of God: A History of the Virgin Mary (London: 2010).

Schumacher L., Divine Illumination: The History and Future of Augustine's Theory of Knowledge (Chichester: 2011).

Serventi S., "Did Giordano da Pisa use the Distinctiones of Nicolas Gorran?", in: Andersson R. (ed.), Constructing the Medieval Sermon, Sermo: Studies on Patristic, Medieval, and Reformation Sermons and Preaching 6 (Turnhout: 2007) 83-116.

Simpson J., "From Reason to Affective Knowledge: Modes of Thought and Poetic Form in Piers Plowman", Medium Aevum 55 (1986) 1-23.

— , "The Rule of Medieval Imagination", in: Dimnick - Simpson - Zeeman, Images, Idolatry, and Iconoclasm 4-24.

Steenbrugge C., "Physical Sight and Spiritual Light in Three Sixteenth-Century Plays of the Low Countries”, Marginalia 3 (2006), electronic article, www.marginalia.co.uk/ journal/o6illumination/steenbrugge.php/.

Steneck N.H., "Albert de Great on the Classification and Localization of the Internal Senses", Isis 65 (1974) 193-211. 
Strohm R., Music in Late Medieval Bruges (Oxford: 1990).

Tachau K.H., Vision and Certitude in the Age of Ockham: Optics, Epistemology and the Foundations of Semantics 1250-1345 (Leiden: 1988).

Van Bruaene A.-L., Om beters wille. Rederijkerskamers en de stedelijke cultuur in de Zuidelijke Nederlanden 1400-1650 (Amsterdam: 2008).

Vance E., "Seeing God: Augustine, Sensation, and the Mind's Eye", in Nichols S.G. Kablitz A. - Calhoun A. (eds.), Rethinking the MedievalSenses:Heritage/Fascinations/ Frames (Baltimore: 2008) 13-29.

Van Nieuwenhove R., An Introduction to Medieval Theology (Cambridge: 2012).

Williamson B., "Sensory Experience in Medieval Devotion", Speculum 88 (2013) 1-43.

Woolgar C.M., The Senses in Late Medieval England (New Haven - London: 2006). 